Prepared in cooperation with the STATE OF HAWAII DEPARTMENT OF TRANSPORTATION

\title{
Rainfall, Streamflow, and Water-Quality Data During Stormwater Monitoring, Halawa Stream Drainage Basin, Oahu, Hawaii, July 1, 2003 to June 30, 2004
}

Open-File Report 2004-1275 


\section{Rainfall, Streamflow, and Water-Quality Data During Stormwater Monitoring, Halawa Stream Drainage Basin, Oahu, Hawaii, July 1, 2003 to June 30, 2004}

By Stacie T.M. Young and Marcael T.J. Ball

Prepared in cooperation with the

STATE OF HAWAII DEPARTMENT OF TRANSPORTATION

Open-File Report 2004-1275 


\title{
U.S. Department of the Interior \\ Gale A. Norton, Secretary \\ U.S. Geological Survey \\ Charles G. Groat, Director
}

\section{U.S. Geological Survey, Reston, Virginia: 2004}

\author{
For sale by U.S. Geological Survey, Information Services \\ Box 25286, Denver Federal Center \\ Denver, CO 80225 \\ For more information about the USGS and its products: \\ Telephone: 1-888-ASK-USGS \\ World Wide Web: http://www.usgs.gov/
}

\footnotetext{
Any use of trade, product, or firm names in this publication is for descriptive purposes only and does not imply endorsement by the U.S. Government.

Although this report is in the public domain, permission must be secured from the individual copyright owners to reproduce any copyrighted materials contained within this report.
} 


\section{Contents}

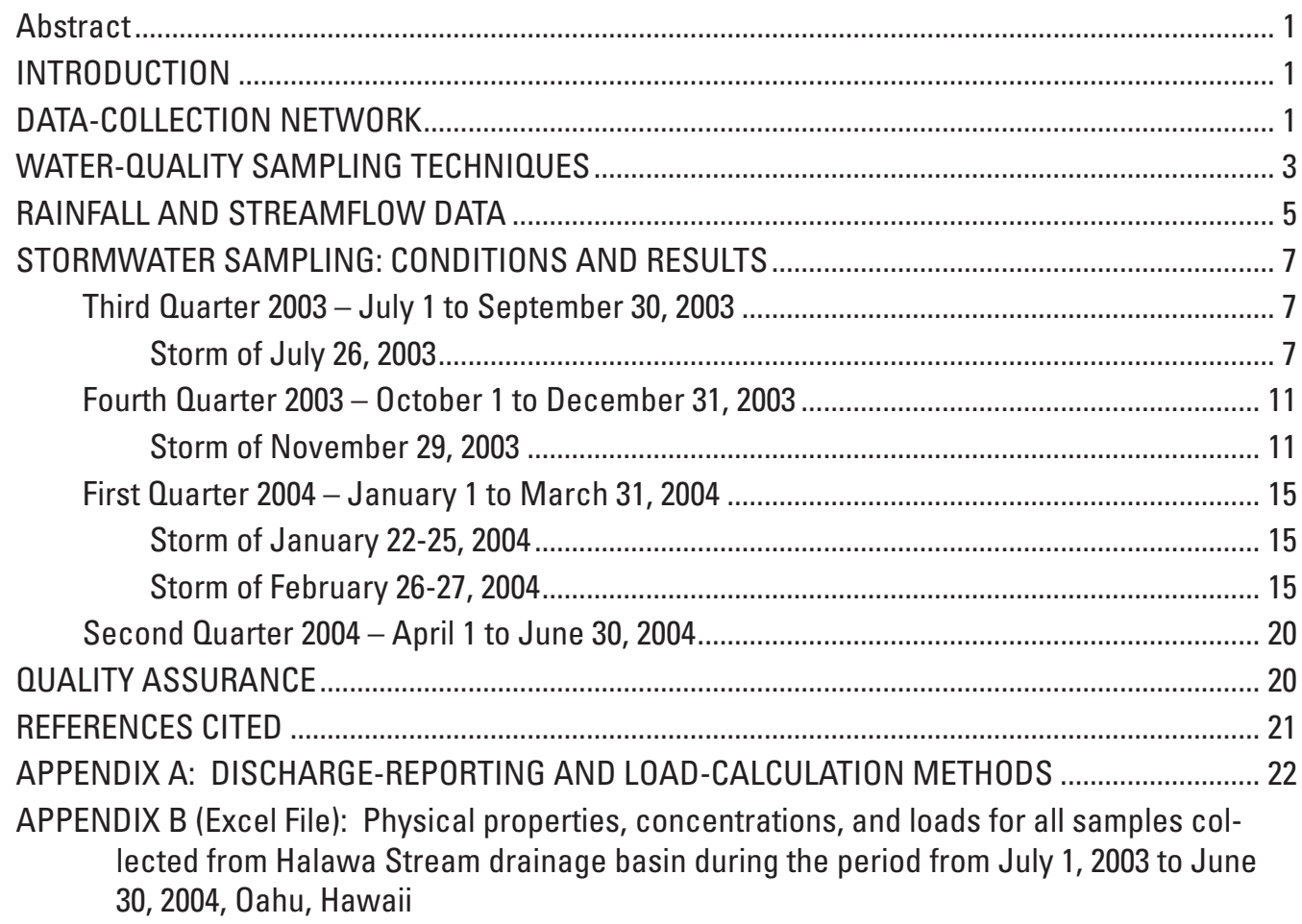

\section{Figures}

Figure 1. Stream-gaging stations, rain gages, and water-quality sampling sites in the Halawa drainage basin, Oahu, Hawaii.

Figure 2. Rainfall and stream discharge for stations within the Halawa Stream drainage basin, Oahu, Hawaii, for July 1, 2003 to June 30, 2004.

Figure 3. Stream discharge at Storm drain C station (212353157533001) for July 1 to September 30, 2003; detail of the 24-hour period of July 26, 2003; and detail of the 7-hour period from 05:00 to 12:00 July 26, 2003, Oahu, Hawaii.

Figure 4. Stream discharge at Xeriscape garden station (16226200) for July 1 to September 30, 2003; detail of the 24-hour period of July 26, 2003; and detail of the 11-hour period from 05:00 to $16: 00$ July 26,2003 , Oahu, Hawaii.

Figure 5. Stream discharge at Quarantine station (16226400) for July 1 to September 30, 2003; detail of the 24-hour period of July 26, 2003; and detail of the 11-hour period from 05:00 to $16: 00$ July 26, 2003, Oahu, Hawaii.

Figure 6. Stream discharge at Storm drain C station (212353157533001) for October 1 to December 31, 2003; detail of the 24-hour period of November 29, 2003; and detail of the 7-hour period from 10:00 to 17:00 November 29, 2003, Oahu, Hawaii.

Figure 7. Stream discharge at Xeriscape garden station (16226200) for October 1 to December 31, 2003; detail of the 24-hour period of November 29, 2003; and detail of the 6-hour period from 12:00 to 18:00 November 29, 2003, Oahu, Hawaii.

Figure 8. Stream discharge at Quarantine station (16226400) for October 1 to December 31, 2003; detail of the 24-hour period of November 29, 2003; and detail of the 6-hour period from 12:00 to 18:00 November 29, 2003, Oahu, Hawaii. 
Figure 9. Stream discharge at Storm drain C station (212353157533001) for January 1 to March 31,2004 ; detail of the 4-day period of January 22-25, 2004; detail of the 1-hour period from 23:00 to 24:00 January 22, 2004; and the detail of the 3-hour period from 15:00 to 18:00 January 25, 2004, Oahu, Hawaii

Figure 10. Stream discharge at Xeriscape garden station (16226200) for January 1 to March 31, 2004; detail of the 4-day period of January 22-25, 2004; detail of the 32-hour period from 05:00 January 22, 2004 to 13:00 January 23, 2004; and the detail of the 3-hour period from 17:00 to 20:00 January 25, 2004, Oahu, Hawaii.

Figure 11. Stream discharge at Storm drain C station (212353157533001) for the 2-day period of February 26-27, 2004; and the detail of the 22-hour period from 13:00 February 26, 2004 to 11:00 February 27, 2004, Oahu, Hawaii. 18

Figure 12. Stream discharge at Xeriscape garden station (16226200) for the 2-day period of February 26-27, 2004; and the detail of the 24-hour period from 14:00 February 26, 2004 to $14: 00$ February $27,2004,0$ ahu, Hawaii.

Figure 13. Stream discharge at Storm drain C (212353157533001) and Xeriscape garden

(16226200) stations for April 1 to June 30, 2004, Oahu, Hawaii.. 20

\section{Tables}

Table 1. Minimum reporting levels of properties and constituents for all samples collected from Halawa Stream drainage basin from July 1, 2003 to June 30, 2004, Oahu, Hawaii.....

Table 2. Significant figures and rounding limits for measured, streamflow-rating, and averaged discharges

Table 3. Conversion factors for computing daily loads from constituent concentration and discharge.

\section{Conversion Factors, Datums, and Abbreviations}

\begin{tabular}{lcl}
\hline Multiply & By & To obtain \\
\hline & Length & \\
inch (in.) & 2.54 & centimeter $(\mathrm{cm})$ \\
foot (ft) & 0.3048 & meter $(\mathrm{m})$ \\
mile (mi) & 1.609 & kilometer $(\mathrm{km})$ \\
& Discharge & \\
cubic foot per second $\left(\mathrm{ft}^{\mathrm{t}} / \mathrm{s}\right)$ & 0.02832 & cubic meter per second $\left(\mathrm{m}^{3} / \mathrm{sec}\right)$ \\
\hline
\end{tabular}

Temperature in degrees Celsius $\left({ }^{\circ} \mathrm{C}\right)$ may be converted to degrees Fahrenheit $\left({ }^{\circ} \mathrm{F}\right)$ as follows:

$$
{ }^{\circ} \mathrm{F}=\left(1.8 \times{ }^{\circ} \mathrm{C}\right)+32
$$

Temperature in degrees Fahrenheit $\left({ }^{\circ} \mathrm{F}\right)$ may be converted to degrees Celsius $\left({ }^{\circ} \mathrm{C}\right)$ as follows:

$$
{ }^{\circ} \mathrm{C}=\left({ }^{\circ} \mathrm{F}-32\right) / 1.8
$$

Vertical coordinate information is referenced relative to mean sea level.

Horizontal coordinate information is referenced to Old Hawaiian Datum.

Specific conductance is given in microsiemens per centimeter at 25 degrees Celsius $(\mu \mathrm{S} / \mathrm{cm}$ at $\left.25^{\circ} \mathrm{C}\right)$.

Concentrations of chemical constituents in water are given either in milligrams per liter (mg/L) or micrograms per liter ( $\mu \mathrm{g} / \mathrm{L})$. 


\section{Rainfall, Streamflow, and Water-Quality Data During Stormwater Monitoring, Halawa Stream Drainage Basin, Oahu, Hawaii, July 1, 2003 to June 30, 2004}

By Stacie T.M. Young and Marcael T.J. Ball

\section{Abstract}

Storm runoff water-quality samples were collected as part of the State of Hawaii Department of Transportation Stormwater Monitoring Program. This program is designed to assess the effects of highway runoff and urban runoff on Halawa Stream. For this program, rainfall data were collected at two sites, continuous streamflow data at three sites, and waterquality data at five sites, which include the three streamflow sites. This report summarizes rainfall, streamflow, and waterquality data collected between July 1, 2003 and June 30, 2004.

A total of 30 samples was collected over four storms during July 1, 2003 to June 30, 2004. In general, an attempt was made to collect grab samples nearly simultaneously at all five sites, and flow-weighted time-composite samples were collected at the three sites equipped with automatic samplers. However, all four storms were partially sampled because either not all stations were sampled or only grab samples were collected. Samples were analyzed for total suspended solids, total dissolved solids, nutrients, chemical oxygen demand, and selected trace metals (cadmium, copper, lead, and zinc). Grab samples were additionally analyzed for oil and grease, total petroleum hydrocarbons, fecal coliform, and biological oxygen demand. Quality-assurance/quality-control samples, collected during storms and during routine maintenance, were also collected to verify analytical procedures and check the effectiveness of equipment-cleaning procedures.

\section{INTRODUCTION}

The State of Hawaii Department of Transportation (DOT) Stormwater Monitoring Program Plan (State of Hawaii Department of Transportation Highways Division, 2002) was implemented on January 1, 2001, to monitor the Halawa Stream drainage basin, Oahu, Hawaii. The Stormwater Monitoring Program Plan was designed to fulfill part of the permit requirements for the National Pollutant Discharge Elimination System program and is revised yearly. The Stormwater Monitoring Program Plan includes the collection of rainfall, streamflow, and water-quality data at selected sites in the Halawa Stream drainage basin.
This report summarizes water-quality data collected by the U.S. Geological Survey (USGS) as part of the Stormwater Monitoring Program Plan. This report presents rainfall, streamflow, and water-quality data collected from July 1, 2003 to June 30,2004 . Descriptions of the sampling techniques are included with the water-quality data.

Four storms were sampled during the period of July 1, 2003 to June 30, 2004. A total of 30 samples were collected during the four storms. In addition, 11 quality-assurance/quality-control (QA/QC) samples were collected: 7 samples were collected concurrently with storm samples during the four storms, and 4 samples were collected between storms during routine cleaning of the sampling equipment. Water-quality data for the QA/QC samples are not published in this report, but are available upon request.

\section{DATA-COLLECTION NETWORK}

Stream-stage, stream-discharge, rainfall, and water-quality data were collected at selected sites in the Halawa Stream drainage basin (fig. 1). Rainfall data were collected at two sites, 212428157511201, North Halawa Valley rain gage at $\mathrm{H}-3$ tunnel portal (abbreviated to Tunnel rain gage) and 212304157542201, North Halawa rain gage near Honolulu (abbreviated to Xeriscape garden rain gage). Streamflow data were collected at three sites in North Halawa Valley since 1998, 1983, and 2001, respectively for stations; 212353157533001, Storm drain C; streamflow-gaging station 16226200, North Halawa Stream near Honolulu ( abbreviated to Xeriscape garden); and 16226400, North Halawa Stream at Quarantine Station (abbreviated to Quarantine station), which was destroyed on December 7, 2003. Rainfall and streamflow data were collected using variable sampling intervals depending on rainfall or streamflow rates. The data from the two rain gages and the three streamflow-gaging stations are transferred daily to the USGS national database using cellular-phone telemetry and can be viewed at http://hi.water.usgs.gov by using the USGS site numbers.

Water-quality data were collected at five sites (fig. 1): 212356157531801, North Halawa Stream at Bridge 8 near Halawa (abbreviated to Bridge 8); Storm drain C; Xeriscape garden; Quarantine station; and 16227100, Halawa Stream 


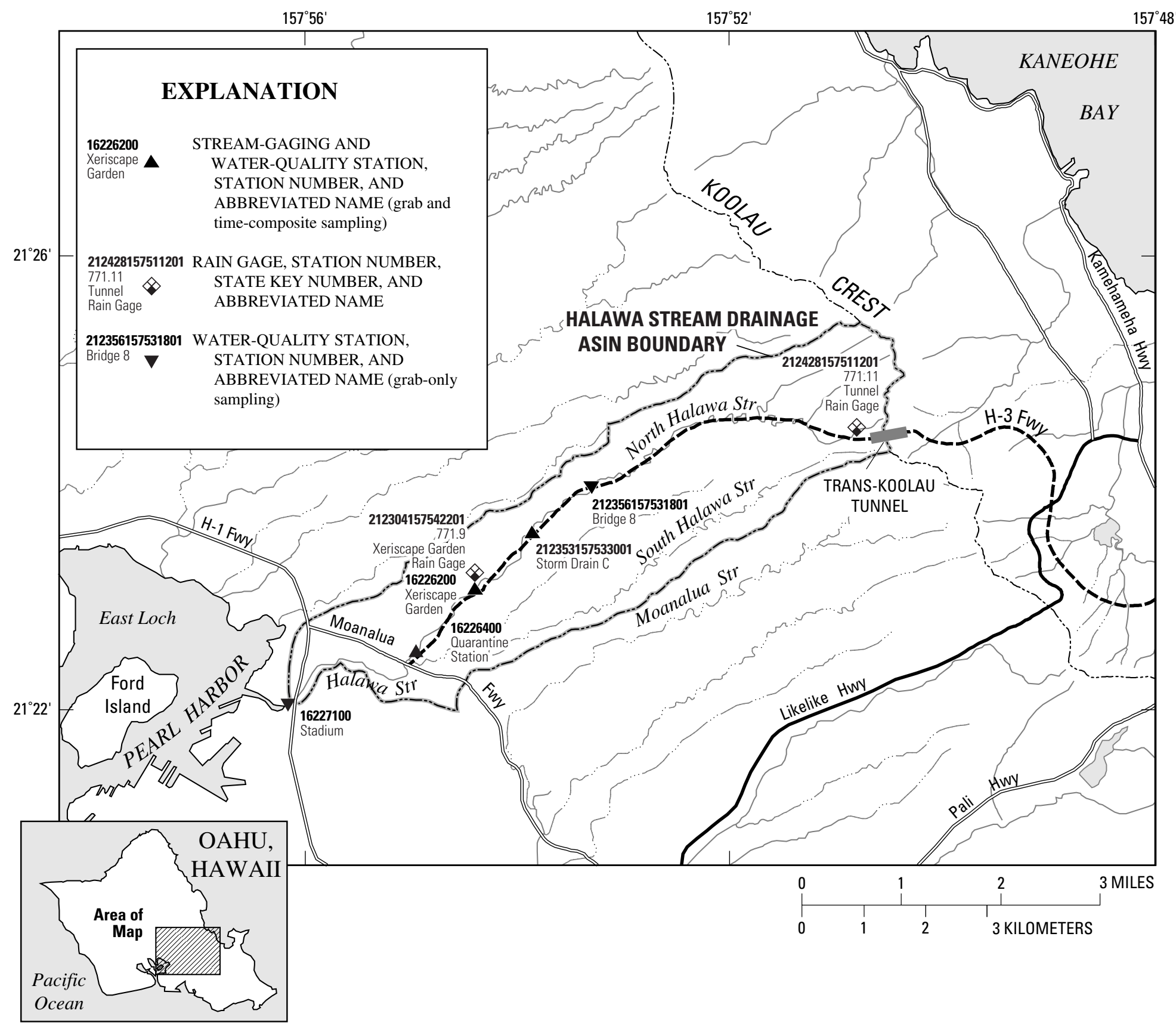



Figure 1. Stream-gaging stations, rain gages, and water-quality sampling sites in the Halawa drainage basin, Oahu, Hawaii. 
below H-1 (abbreviated to Stadium). The Bridge 8 site is about $0.75 \mathrm{mi}$ above the discharge point of Storm drain $\mathrm{C}$ on North Halawa Stream. Storm drain C collects runoff from an approximately 4-mi length of freeway from the tunnel portal to mid-valley and discharges directly to North Halawa Stream (fig. 1). The Xeriscape garden gage is directly upstream from a light-industrial area near North Halawa Stream, and about $0.75 \mathrm{mi}$ downstream of the discharge point of Storm drain C. The Quarantine station is about $1 \mathrm{mi}$ downstream of Xeriscape garden and near the downstream end of the light-industrial area that borders the North Halawa Stream. The Stadium site is about $0.5 \mathrm{mi}$ downstream of the Quarantine station, below the confluence of North and South Halawa Streams, downstream from the crossing of $\mathrm{H}-1$ freeway, and directly upstream from the mouth of Pearl Harbor. Water-quality data have been previously collected at Storm drain C (1998-present), Xeriscape garden (1983-present), and Stadium (1988present) by the USGS as part of the H-3 freeway construction monitoring study and can be viewed at http://waterdata.usgs. gov/hi/nwis/qwdata using the site numbers.

\section{WATER-QUALITY SAMPLING TECHNIQUES}

Water-quality samples include grab samples collected manually, grab samples collected by the automatic sampler, and flow-weighted time-composite samples collected by the automatic sampler.

Sampling requirements.--The DOT Stormwater Monitoring Program Plan states that water-quality samples will be collected at least once per quarter during periods of storm runoff from each of the five water-quality monitoring stations (fig. 1). The plan also states that efforts will be made to sample from all five water-quality monitoring stations during a single storm, and if a storm does not occur during a quarter, no samples will be collected.

A complete storm sample for all 5 sites consists of five grab samples, three flow-weighted time-composite samples, and one QA/QC sample. However, some storms are brief and do not produce adequate runoff to sample all five sites and collect all samples. In practice, these storms have been sampled as thoroughly as possible and analyzed for as many constituents as practical. In previous years, three QA/QC samples were collected and considered part of a complete storm sample, although the DOT Stormwater Monitoring Program Plan required only one QA/QC sample to be collected per storm sample. Because of increased laboratory analysis costs after December 2003, the number of QA/QC samples was reduced to the required one sample per storm.

Storm criteria.--The U.S. Environmental Protection Agency's (USEPA) Storm Water Sampling Guidance Manual (U.S. Environmental Protection Agency, Office of Water, 1993) provides guidelines for stormwater-sampling criteria. The first criterion requires at least $0.1 \mathrm{in}$. of accumulated rainfall. Rainfall accumulations have exceeded $0.1 \mathrm{in}$. at the Tunnel rain gage and Xeriscape garden rain gage when stormwater sampling was conducted. The second criterion requires that samples be collected only for storms preceded by at least 72 hours of dry weather. The second criterion would prevent sampling of most storms on North Halawa Stream because the Halawa Stream drainage basin, as well as many other parts of the island, receives tradewind showers almost daily.

In practice, criteria used to initiate sampling of the stream and storm drain were based on the rate of rainfall accumulation and the rise of stage in Storm drain C, Xeriscape garden, and Quarantine station. Each automatic sampler is triggered at predetermined stream-stage thresholds, depending on the site. The automatic samplers at Storm drain C, Xeriscape garden, and Quarantine station collect samples at stages that correspond to discharges greater than $3 \mathrm{ft}^{3} / \mathrm{s}, 40 \mathrm{ft}^{3} / \mathrm{s}$, and $41 \mathrm{ft}^{3} / \mathrm{s}$, respectively.

Sample collection.-- In general, grab samples were collected manually using isokinetic, depth-integrating samplers and equal-width increment (EWI) sampling techniques (Wilde and others, 1998). The sampler is made of high-density polyethylene (HDPE) and collects water in an isokinetic manner, in which water enters the sampler at the same velocity as the stream. The EWI sampling technique utilizes evenly spaced sampling increments along the cross section of the stream. The volume of sample collected at each increment is proportional to the discharge at that increment. Samples collected at each increment are combined in an HDPE churn.

An EWI sample is practical when depths are greater than $0.5 \mathrm{ft}$ and the stream is wadeable. During high-discharge storms, streams were not waded for safety reasons. However, the stream appeared to be well mixed during high-discharge storms at each site such that the EWI method was not necessary. At such times, the grab sample was collected by an isokinetic sampler from a single vertical section at the estimated centroid of flow of the stream. Sub-samples from the singlevertical technique were combined in an HDPE churn.

A flow-weighted, time-composite sample is created by combining, in a HDPE churn, all or part of the samples collected by the automatic sampler. The desired volume of water from each sample is proportional to the stream-discharge volume between sample-collection times.

Composite samples were collected over a time period that sometimes lasted several hours using an automatic sampler. Automatic samplers collect water from a fixed point in the stream channel after pre-determined stage thresholds are met. The automatic samplers have a capacity of 24, 1-liter bottles. When the first threshold was met, the automatic samplers were programmed to sample water every 2 minutes for the first five samples, and then every 15 minutes. When a higher, second threshold was met, the automatic samplers were programmed to sample water every 7 minutes.

The first five samples from the automatic sampler were collected at 2-minute intervals and were sometimes combined and analyzed as a grab sample when grab samples could not be collected manually. The first three of these five samples 
were collected in teflon bags. In the event that a manual grab sample could not be collected, the samples in teflon bags were sometimes used for oil and grease $(\mathrm{O}+\mathrm{G})$ and total petroleum hydrocarbon (TPH) analyses. The remaining 21 samples were collected in low density polyethylene (LDPE) bags.

The main limitation associated with using samples from the automatic sampler is that some constituents require the sample to be chilled prior to analysis or analyzed within a certain time after collection, known as a holding time. The automatic samplers were not equipped with refrigeration units, and thus holding times for constituents may have been exceeded.

Samples collected by the automatic sampler (automatic samples) may be used in lieu of or in addition to manual grab samples. Thus, there may be more than five grab samples in a sample set or more than one grab sample at a site. Automatic samples were used in lieu of a manual grab sample when a manual grab sample could not be collected because of insufficient runoff at the time of the site visit. Automatic samples were used in addition to a manual grab sample when the automatic samples were collected during the first peak or first flush of the storm. When a few hours separated the sample times at which the samples were filled, the bottles were not combined into a single composite sample because it would not represent the first flush of the storm.

If the first five automatic samples were collected from the same peak, these samples would be representative of a first flush sample and would be analyzed as a grab sample. The first samples, collected in teflon bags, would be for $\mathrm{O}+\mathrm{G}$ analysis and the second sample bottle for TPH analysis. The entire contents of the other three sample bottles would be combined and analyzed for total suspended solids (TSS), total dissolved solids (TDS), nutrients, chemical oxygen demand (COD), and selected trace metals (cadmium, copper, lead, and zinc). Fecal coliform (FC) and biological oxygen demand (BOD) would not be analyzed in this case because the holding times for these constituents would likely be exceeded.

Determination of discharge.--At the Bridge 8, Storm drain C, Xeriscape garden, and Quarantine station sites, discharge associated with each sample was determined using a streamflow rating, created for the site, or by measurement using a current meter. Streamflow ratings were developed by measurements and computer modeling, and verified by subsequent measurements. At the Stadium site, the wide and curving concrete-lined channel and shallow and swift streamflow precluded development of an accurate streamflow rating. Discharge at this site was measured using a current meter. At higher flows, discharge was measured either by using float-measurement techniques or a radar gun. The float-measurement technique involves timing floating bottles over a known distance to determine velocity. The radar gun measures surface velocity at a single point in the cross section. In both techniques, the area of the cross section was estimated by the depth of water and surveyed dimensions of the channel. USGS practices for making discharge measurements and streamflow ratings can be found in Rantz and others (1982).
An average-discharge value was calculated for each composite sample. The average-discharge value was equal to the total volume of water that flowed by the gaging station during sample collection, divided by the total elapsed time during sample collection (for only the samples used for the composite). To determine the volume of water that passed the station for each sample, the discharge at the time of sample collection was multiplied by the elapsed time between each sample collected. The same time increment between the first and second samples was assigned to the first sample. These volumes were summed, and the total volume was divided by the sum of all the time increments.

Measured, streamflow-rating, and averaged discharge values are reported to appropriate number of significant figures. These discharge values and the corresponding values of constituent concentration are used to compute loads. Reported discharge values and the calculation of loads are discussed in appendix A.

Sample processing, analysis, and quality-assurance/ quality control.--USGS water-quality sampling methods (Wilde and others, 1998) were followed to prevent possible contamination during sample processing. Both grab and composite samples were processed using churns to mix and suspend sediment while delivering the sample to specific bottles for the various constituent analyses. The time assigned to each grab and composite sample is the median time of the sample collection.

As required by the DOT Stormwater Sampling Program Plan, each composite and grab sample was analyzed for temperature, $\mathrm{pH}$, specific conductance, TSS, TDS, nutrients, COD, and selected trace metals (cadmium, copper, lead, and zinc). Each grab sample was also analyzed for $\mathrm{O}+\mathrm{G}, \mathrm{TPH}$, FC, and BOD. USGS personnel made field measurements of temperature, $\mathrm{pH}$, and specific conductance. The minimum reporting levels for each of the analyzed properties and constituents are listed in table 1 and are based on values published by the USGS National Water Quality Laboratory (NWQL). Calculated values, organic nitrogen and total nitrogen, do not have minimum reporting levels. More information about minimum reporting levels and how they are determined by NWQL can be found in Childress and others (1999).

FC and BOD analyses were performed by Aecos Incorporated, a private laboratory on Oahu. QA/QC practices at Aecos Incorporated are conducted, but are not published. For stormsample events that occurred on a weekend or holiday, no FC or BOD samples were collected because Aecos Incorporated was closed. All other analyses were performed at the USGS NWQL, in Denver, Colorado. The methods used for analyses of all water-quality constituents and quality-control practices at NWQL are documented in Friedman and Erdmann (1982), Fishman and Friedman (1989), Pritt and Raese (1992), Patton and Truitt (1992) and Fishman (1993).

Three different QA/QC samples were collected at designated sites during each storm prior to December 2003. A field duplicate, which is a sample that is split into two during sample processing, was collected at Bridge 8. A laboratory 
Table 1. Minimum reporting levels of properties and constituents for all samples collected from Halawa Stream drainage basin from July 1, 2003 to June 30, 2004, Oahu, Hawaii

[std., standard; $\mu \mathrm{S} / \mathrm{cm}$, microsiemens per centimeter at $25^{\circ} \mathrm{C} ; \mathrm{mg} / \mathrm{L}$, milligrams per liter; ${ }^{\circ} \mathrm{C}$, degrees Celsius; $\mu \mathrm{g} / \mathrm{L}$, micrograms per liter; --, no minimum reporting level, computed value; MPN/100 mL, most probable number (of colonies) per 100 milliliters]

Property or constituent

$\mathrm{pH}$

Specific conductance

Temperature

Total suspended solids

Total dissolved solids

Total nitrogen ${ }^{\mathrm{a}}$

Organic nitrogen ${ }^{\mathrm{b}}$

Nitrogen ammonia dissolved

Nitrogen, total organic + ammonia $^{c}$

Nitrogen, nitrite + nitrate dissolved

Phosphorus dissolved

Total phosphorus

Chemical oxygen demand

Total cadmium

Total copper

Total lead

Total zinc

Oil and grease

Total petroleum hydrocarbons

Biological oxygen demand

Fecal coliform
Minimum reporting levels

0.1 std. units

$2.6 \mu \mathrm{S} / \mathrm{cm}$

$0.5^{\circ} \mathrm{C}$

$10 \mathrm{mg} / \mathrm{L}$

$10 \mathrm{mg} / \mathrm{L}$

$0.04 \mathrm{mg} / \mathrm{L}$

$0.10 \mathrm{mg} / \mathrm{L}$

$0.060 \mathrm{mg} / \mathrm{L}$

$0.04 \mathrm{mg} / \mathrm{L}$

$0.040 \mathrm{mg} / \mathrm{L}$

$10 \mathrm{mg} / \mathrm{L}$

$0.04 \mu \mathrm{g} / \mathrm{L}$

$0.6 \mu \mathrm{g} / \mathrm{L}$

$0.06 \mu \mathrm{g} / \mathrm{L}$

$2 \mu \mathrm{g} / \mathrm{L}$

$7 \mathrm{mg} / \mathrm{L}$

$2 \mathrm{mg} / \mathrm{L}$

$1 \mathrm{mg} / \mathrm{L}$

$2 \mathrm{MPN} / 100 \mathrm{~mL}$

${ }^{a}$ Total nitrogen is calculated by adding nitrogen, total organic + ammonia (Kjeldahl) to nitrite+nitrate, dissolved.

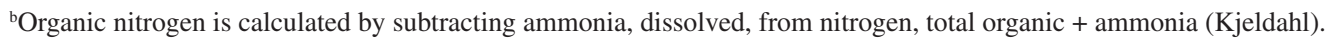

'Nitrogen, ammonia dissolved, plus total nitrogen, is total Kjeldahl nitrogen.

duplicate, which is a sample that is analyzed twice at the laboratory, was collected at Quarantine station. A spiked sample, created by a part of the storm sample and spiked at the NWQL with a known quantity of analyte, was collected at Xeriscape garden. As mentioned previously, only a field duplicate was required by the Stormwater Sampling Program Plan per storm sample. Therefore, due to an increase in analytical costs, QA/ QC samples collected during storms sampled after December 2003 were limited to field duplicates. The site where the field duplicate was collected varied by storm.

During the period between storms, non-dedicated and non-disposable equipment, such as churns, isokinetic samplers, automatic-sampler intake lines, and teflon automaticsampler bottle liners, were cleaned following procedures in Wilde and others (1998). Field-blank samples were collected once per quarter. Inorganic blank water (IBW), free of inor- ganic constituents, was passed through this equipment and collected. The IBW field-blank samples were analyzed for the same inorganic constituents as the storm samples. Data presented in this report are provisional and subject to revision.

\section{RAINFALL AND STREAMFLOW DATA}

Hydrographs of daily rainfall and daily mean streamflow data for the period of July 1, 2003 through June 30, 2004 are shown in figure 2. A total of $190.8 \mathrm{in}$. of rain was recorded at the Tunnel rain gage and $62.4 \mathrm{in}$. of rain was recorded at Xeriscape garden rain gage between July 1, 2003 through June 30, 2004. 

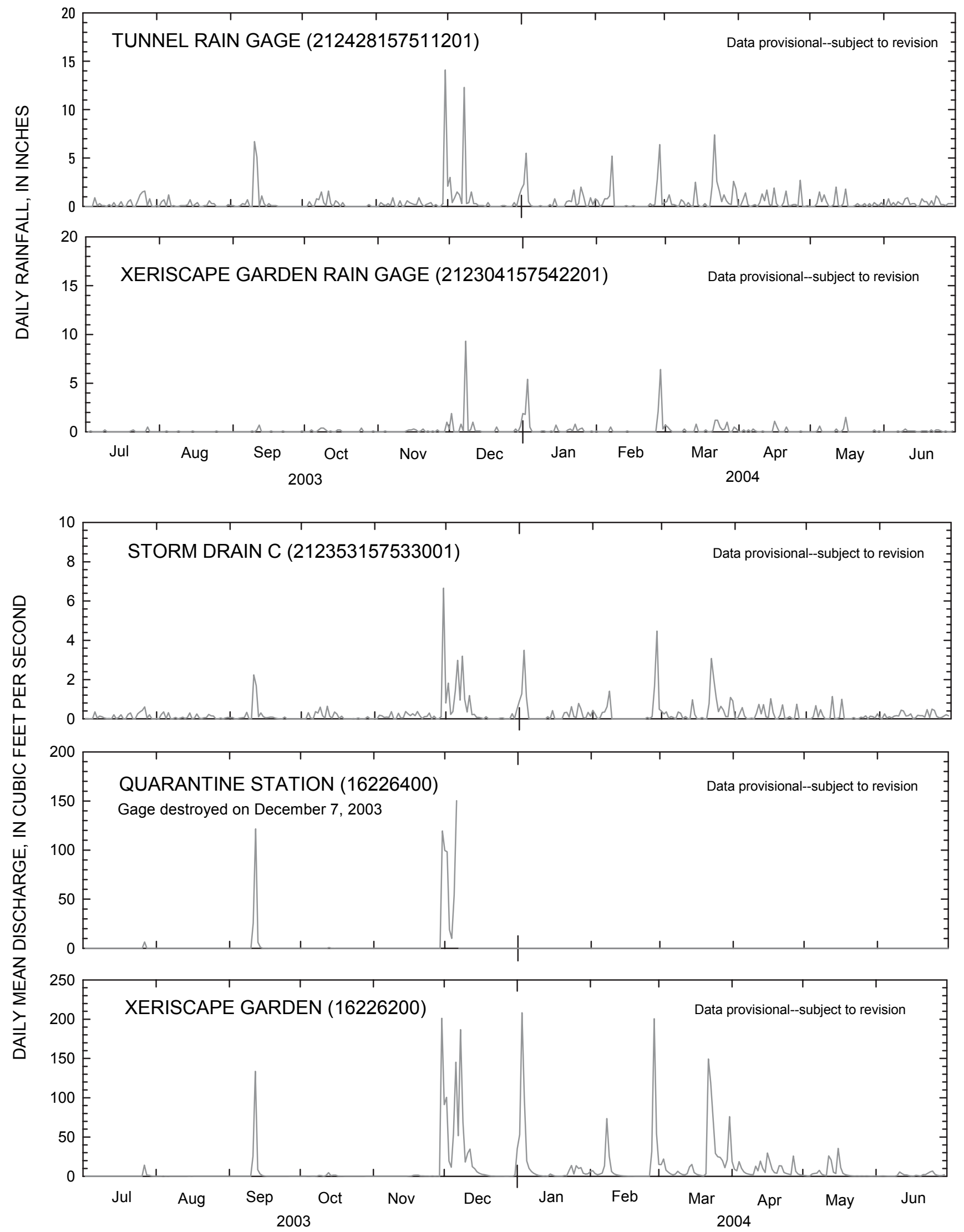

Figure 2. Rainfall and stream discharge for stations within the Halawa Stream drainage basin, Oahu, Hawaii, for July 1, 2003 to June 30, 2004. 
Days with daily rainfall values greater than 1.6 in. at the Tunnel rain gage and daily rainfall values greater than $0.4 \mathrm{in}$. at the Xeriscape garden rain gage resulted in sufficient runoff for collection of a storm sample. The highest recorded daily rainfall at the Tunnel rain gage was 14.1 in. on November 29, 2003. The highest recorded daily rainfall at the Xeriscape garden rain gage was 9.3 in. on December 7, 2003. The recorder malfunctioned during the period of December 4-12, 2003 at the Tunnel rain gage and during March 2-6, 14, 22-31, and April 1, 2004 at Xeriscape garden rain gage. Daily rainfall was estimated during the periods of recorder malfunction.

Halawa Stream is an intermittent stream. The longest record of streamflow and water-quality data for the stations operated for this project is from the Xeriscape garden gage, which was part of a network of gages for the H-3 Highway construction project (1983-2000). At Xeriscape garden streamflow-gaging station, the highest daily mean discharge was 208 $\mathrm{ft}^{3} / \mathrm{s}$ on January 2, 2004. The longest period of zero flow at this station was from July 1 to July 25, 2003. At the Quarantine station gaging station, the highest daily mean discharge was $150 \mathrm{ft}^{3} / \mathrm{s}$ on December 5, 2003. The longest period of zero flow at this station was from October 15 to November 28, 2003. For Storm drain C, the highest daily mean discharge was $6.7 \mathrm{ft}^{3} / \mathrm{s}$ on November 29,2003 . The longest period of zero flow at this station was from February 8-22, 2004.

\section{STORMWATER SAMPLING: CONDITIONS AND RESULTS}

During the period July 1, 2003 through June 30, 2004, at least ten storms occurred with sufficient runoff to trigger the automatic samplers at the predetermined thresholds. Of these storms, four were sampled: July 26, 2003, November 29, 2003, January 22-25, 2004, and February 26-27, 2004. Due to events held at the Aloha Stadium, adjacent to Stadium station and the destruction of Quarantine station gage on December 7, 2003, complete storm samples were not possible for this year. A complete storm sample for all 5 sites consists of five grab samples, three flow-weighted time-composite samples, and one QA/QC sample.

\section{Third Quarter 2003 - July 1 to September 30, 2003}

\section{Storm of July 26, 2003}

During third quarter 2003, the July 26, 2003 storm was sampled. Hydrographs of streamflow at Storm drain C, Xeriscape garden, and Quarantine station during the storm are shown in figures 3, 4, and 5, respectively. Grab sample-collection times are displayed on the hydrographs. Discharges and analyzed constituents are shown in appendix B.
Automatic samples were collected during this storm at Storm drain C, Xeriscape garden and Quarantine station. However, due to insufficient number of samples collected or sampler-equipment malfunction, flow-weighted time-composite samples were not created. Samples collected by the automatic sampler were analyzed as grab samples. Manual grab samples were collected from each site, except for Stadium. Stadium was not sampled due to adjacent activities (carnival and flea market). Samples were analyzed for all constituents listed in the Stormwater Monitoring Program Plan (State Department of Transportation, 2002).

Bridge 8.--The grab sample was collected using the EWI method at 16 sampling points spaced every foot along a cross section of the stream. The stream width was about $17 \mathrm{ft}$ and the discharge was concentrated in the middle $6 \mathrm{ft}$ of the cross section used for sampling. A field duplicate was collected at this site. Discharge was measured concurrently with the sample collection using a current meter and was $31.4 \mathrm{ft}^{3} / \mathrm{s}$.

Storm drain C.-- Two grab samples were collected. The 7 samples collected on July 26, 2003 by the automatic sampler, representing the first flush, were analyzed as a grab sample. The first two samples, collected in Teflon bags, were used for $\mathrm{O}+\mathrm{G}$ and $\mathrm{TPH}$ analysis. The remaining 5 samples were all combined in a churn and were not flow-weighted. The average discharge was $6.6 \mathrm{ft}^{3} / \mathrm{s}$. The second grab sample was collected at the centroid of flow in the storm drain by directly submersing the churn. At the time of manual-grab sample, the discharge was $0.88 \mathrm{ft}^{3} / \mathrm{s}$ (fig. 3). Discharge associated with the grab sample was determined using the stage at the mean time of the grab-sample collection and the streamflow rating for this gage.

Xeriscape garden.-- Two grab samples were collected. A total of 14 samples were triggered on July 26, 2003 by the automatic sampler, but due to a kink in the sampler line, only five samples bags filled. All 5 samples, representing the first flush were combined in a churn and analyzed as the first grab sample. $\mathrm{O}+\mathrm{G}$ and TPH samples were not analyzed. The average discharge was $52 \mathrm{ft}^{3} / \mathrm{s}$. The second grab sample was collected using the EWI method at 10 sampling points distributed every foot along the cross section of the stream. The width was about $12 \mathrm{ft}$. A laboratory spike sample was collected at this site. At the time of manual-grab sample, the discharge was $11 \mathrm{ft}^{3} / \mathrm{s}$ (fig. 4). Discharge associated with the grab sample was determined using the stage at the mean time of the grab-sample collection and the streamflow rating for this gage.

Quarantine station.--One grab sample was collected. Three samples were collected on July 26, 2003 by the automatic sampler. One of the three sample-collection bags leaked, resulting in insufficient sample volume to create a composite or a grab sample. The grab sample was collected using the EWI method at 14 sampling points distributed every foot along the cross section of the stream. The stream width was about $14 \mathrm{ft}$. A laboratory-duplicate sample was collected at this site. At the time of the grab sample, the discharge was $11 \mathrm{ft}^{3} / \mathrm{s}$ (fig. 5). Discharge associated with the grab sample 


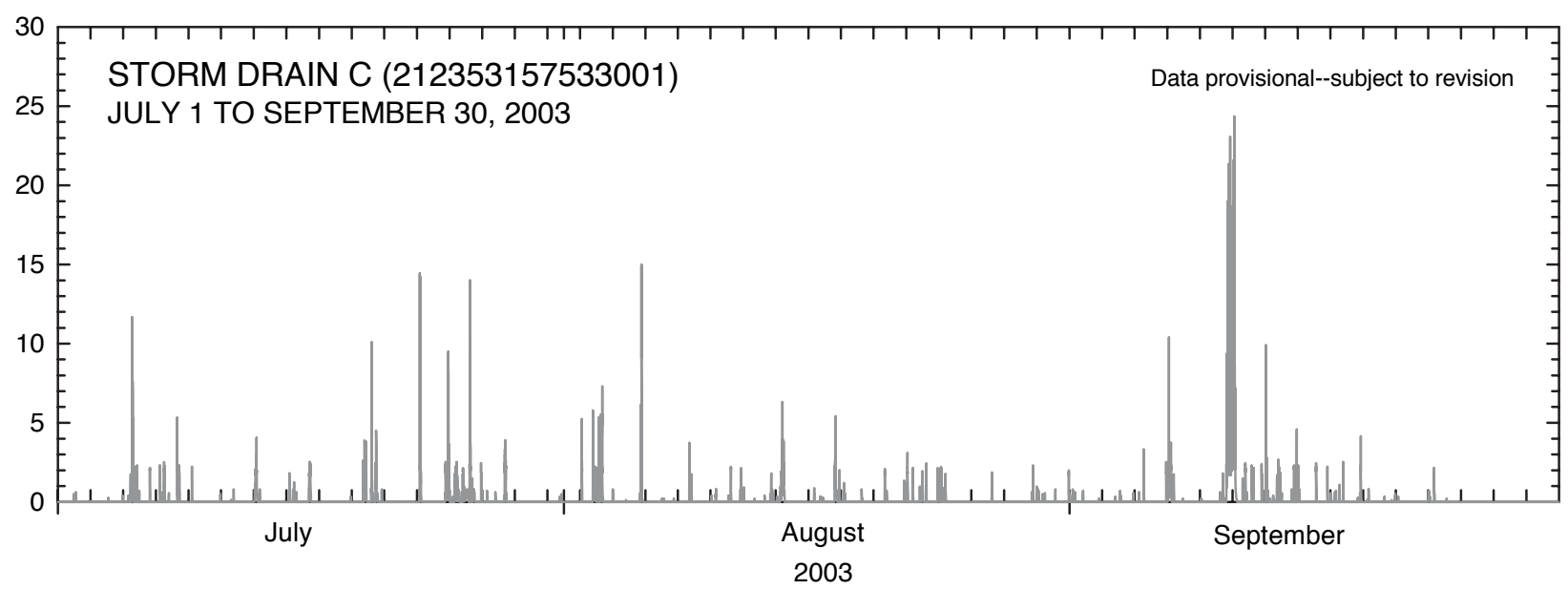

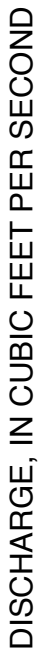
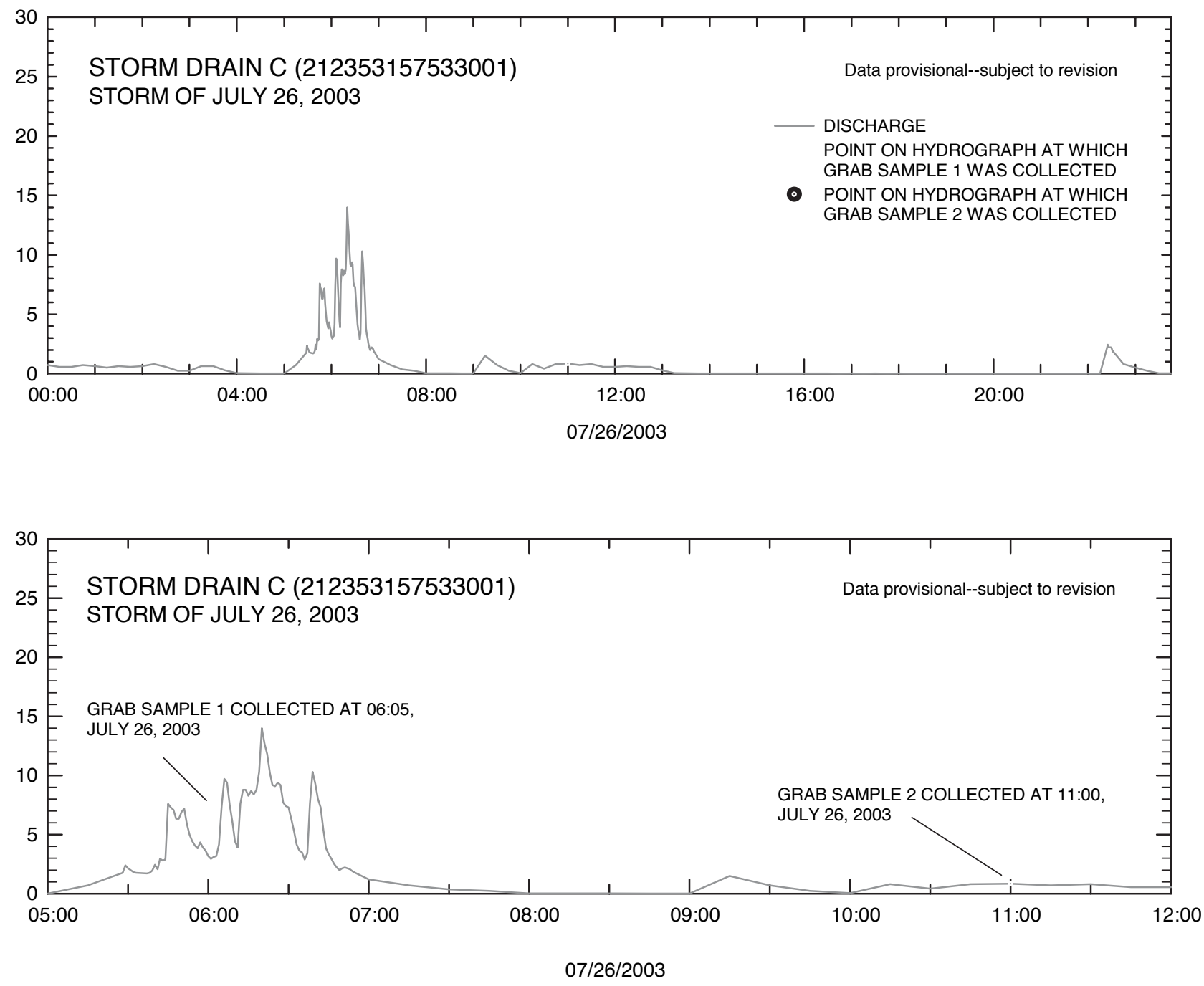

Figure 3. Stream discharge at Storm drain C station (212353157533001) for July 1 to September 30, 2003; detail of the 24-hour period of July 26, 2003; and detail of the 7-hour period from 05:00 to 12:00 July 26, 2003, Oahu, Hawaii. 


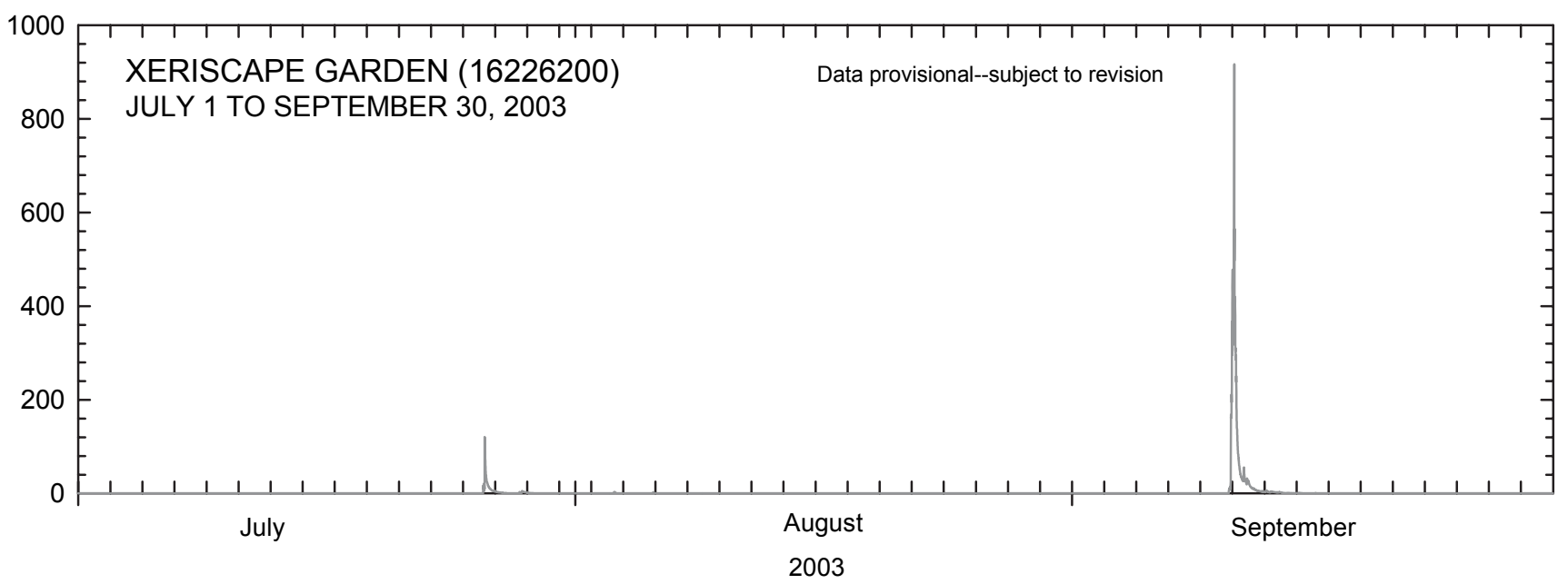

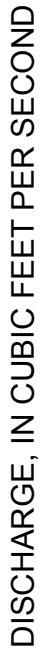
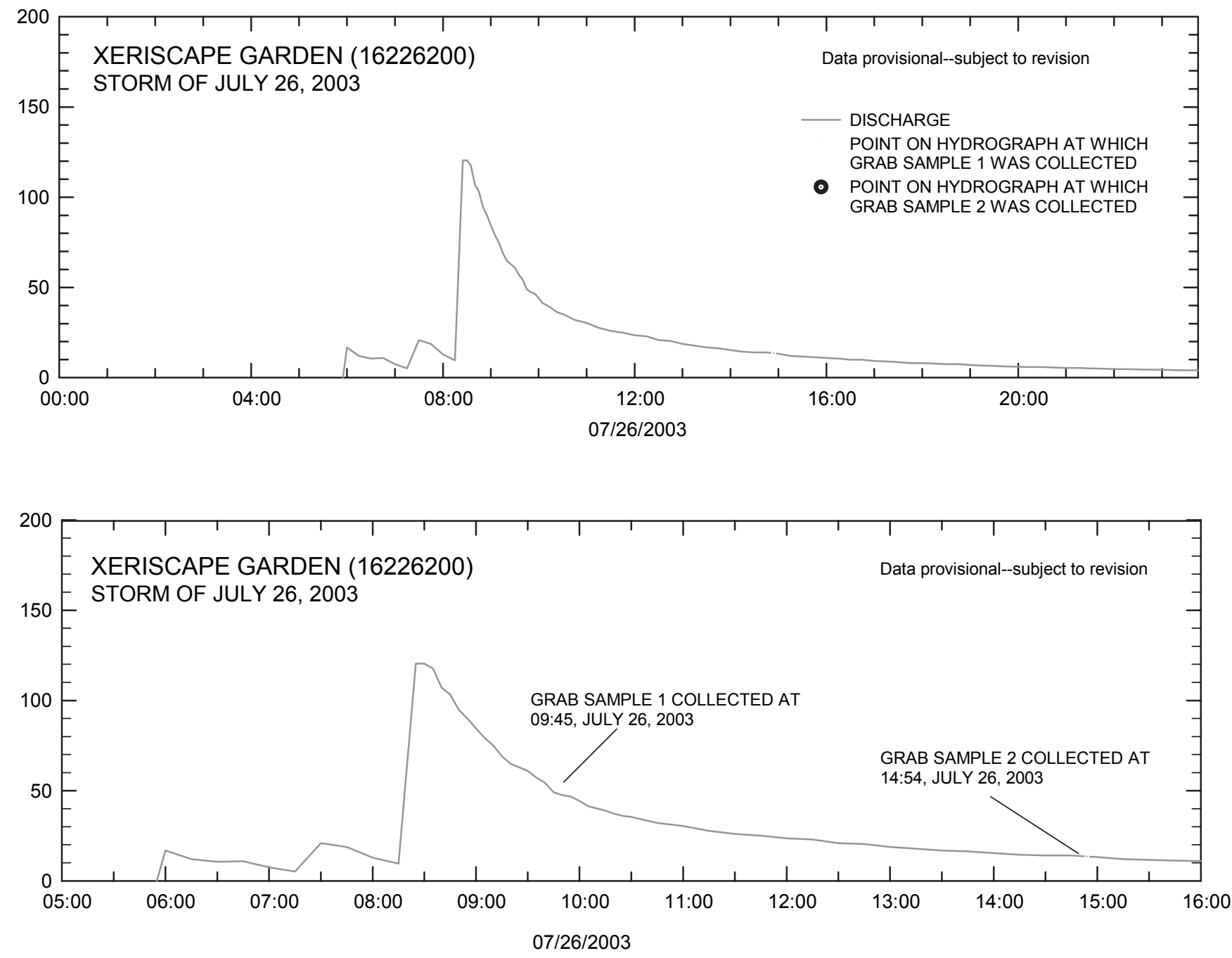

Figure 4. Stream discharge at Xeriscape garden station (16226200) for July 1 to September 30, 2003; detail of the 24-hour period of July 26, 2003; and detail of the 11-hour period from 05:00 to 16:00 July 26, 2003, Oahu, Hawaii. 


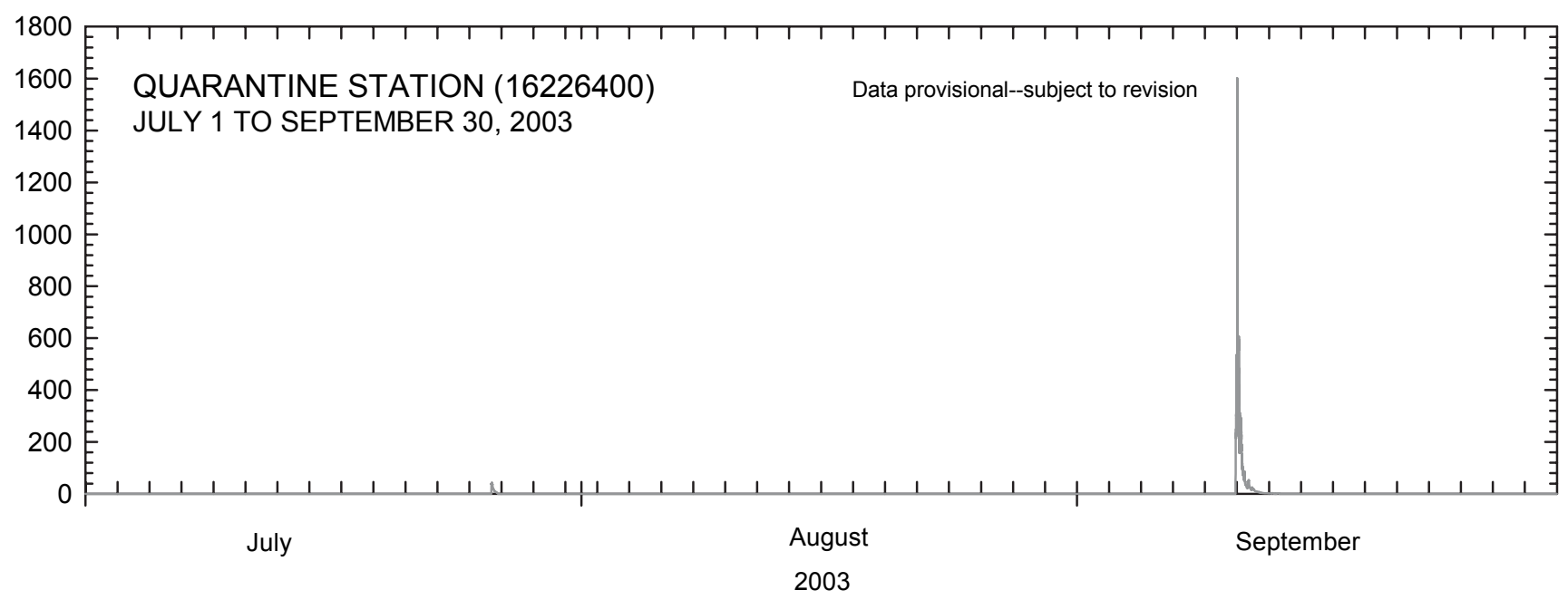

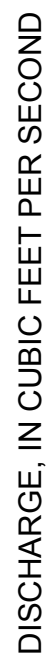
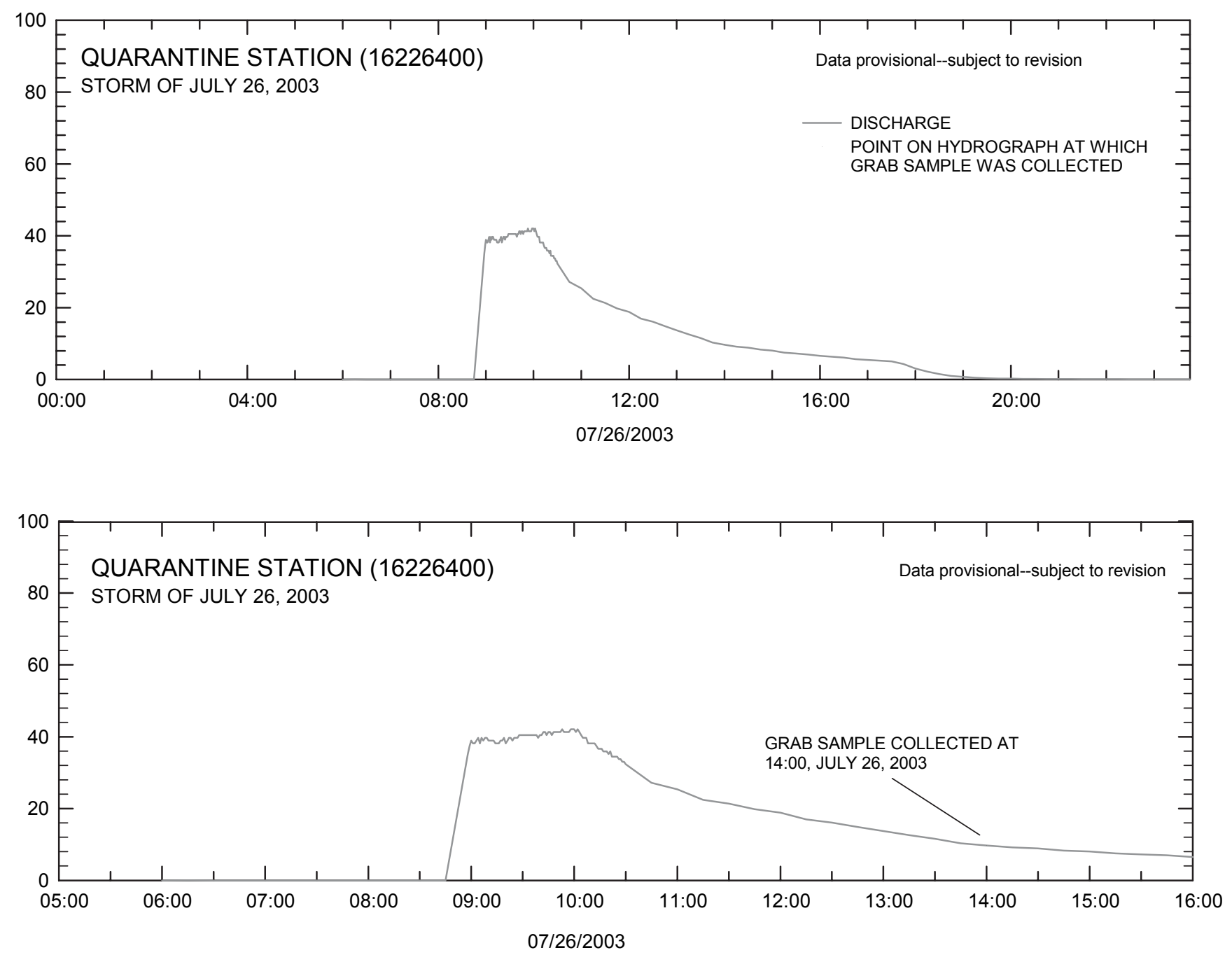

Figure 5. Stream discharge at Quarantine station (16226400) for July 1 to September 30, 2003; detail of the 24-hour period of July 26, 2003; and detail of the 11-hour period from 05:00 to 16:00 July 26, 2003, 0ahu, Hawaii. 
was determined using the stage at the mean time of the grabsample collection and the streamflow rating for this gage.

\section{Fourth Quarter 2003 - October 1 to December 31, 2003}

\section{Storm of November 29, 2003}

During fourth quarter 2003, the November 29, 2003 storm was sampled. Hydrographs of streamflow at Storm drain C, Xeriscape garden, and Quarantine station during the storm are shown in figures 6,7 , and 8 , respectively. Beginning and end times for composite-sample collection are displayed on the hydrographs. No FC or BOD samples were collected during this storm.

A total of four composite samples was collected, one each from Storm drain C and Quarantine station, and two from Xeriscape garden. Four manual grab samples and two automatic grab samples were collected during this storm. Stadium was not sampled due to public events (carnival and flea market). Samples were analyzed for all constituents, except for FC and BOD samples, listed in the Stormwater Monitoring Program Plan (State Department of Transportation, 2002). Discharge, temperature, $\mathrm{pH}$, and specific-conductance values from field measurements and constituent concentrations and average loads for the grab and composite samples are shown in appendix B.

Bridge 8.--The grab sample was collected using the EWI method at 5 sampling points spaced every $2 \mathrm{ft}$ along a cross section of the stream. The stream width was about $36 \mathrm{ft}$ and the discharge was concentrated in the middle $4 \mathrm{ft}$ of the cross section which was sampled for $\mathrm{O}+\mathrm{G}, \mathrm{TPH}$, and field specific conductivity and $\mathrm{pH}$. A field duplicate was collected at this site. During the processing of this sample it was observed that the churn had a leaky spigot and an insufficient volume of sample water remaining to process the bottles for metals and nutrients for the field duplicate. However, $\mathrm{O}+\mathrm{G}$ and $\mathrm{TPH}$ field-duplicate samples were collected and the remaining sample from these bottles was used to analyze for metals and nutrients at NWQL. Discharge was measured concurrently with the sample collection using a current meter and was 689 $\mathrm{ft}^{3} / \mathrm{s}$.

Storm drain C.--One grab sample was collected at the centroid of flow in the storm drain by directly submersing the churn. At the time of the grab sample, the discharge was 24 $\mathrm{ft}^{3} / \mathrm{s}$ (fig. 6). Discharge associated with the grab sample was determined using the stage at the mean time of the grab-sample collection and the streamflow rating for this gage.

The automatic sampler collected a total of 24 samples during the storm. The first 7 samples were omitted due to the large time difference between each of the samples. The time difference ranged from 2-5 hours. The last 17 samples, collected by the automatic sampler, were used to create a flowweighted, time-composite sample. The peak discharge was 33 $\mathrm{ft}^{3} / \mathrm{s}$ on November 29, 2003 at 13:31. The average discharge was $15 \mathrm{ft}^{3} / \mathrm{s}$.

Xeriscape garden.--Two grab samples were collected. The first 3 automatic samples were collected in Teflon bags and the first two automatic samples were omitted due to leakage of the bags. Therefore, the first grab sample was from the automatic sampler and was only tested for $\mathrm{O}+\mathrm{G}$ using the remaining automatic sample collected in a Teflon bag that represented the first flush. The discharge of $38 \mathrm{ft}^{3} / \mathrm{s}$ (fig. 7) was determined using the stage at the time the sample was taken and the streamflow rating from this gage. The second grab was collected by dipping the churn at the centroid of flow from the right bank. At the time sample of collection, the stream was unsafe to wade and well mixed. The discharge was $640 \mathrm{ft}^{3} / \mathrm{s}$ (fig. 7). Discharge associated with the second grab sample was determined using the stage at the mean time of the grabsample collection and the streamflow rating from this gage. A laboratory-spike sample was collected at this site.

The automatic sampler collected a total of 24 samples during a 3-hour period. As mentioned above, the first two sample bags leaked and the third sample was used for the first grab sample. Two samples were omitted due to the large time difference of 1-hour. Three samples bags were found empty. With the remaining samples, two composite samples were created. The first composite sample consisted of 5 samples collected on the rise of the peak and was not flow-weighted time-composited. The average discharge for this sample was $303 \mathrm{ft}^{3} / \mathrm{s}$ (fig. 7). The second composite sample consisted of 9 samples collected at the peak of discharge and was flowweighted time-composited. The peak discharge was $1,570 \mathrm{ft}^{3} / \mathrm{s}$ (21:30) on November 29, 2003. The average discharge for the composite sample was $641 \mathrm{ft}^{3} / \mathrm{s}$.

Quarantine station.--Two grab samples were collected. The first grab was from the automatic sampler. One of the first 3 automatic samples collected in Teflon bags was used and only tested for $\mathrm{O}+\mathrm{G}$ because it represented the first flush. The discharge was $56 \mathrm{ft}^{3} / \mathrm{s}$ (fig. 8), and determined using the stage at the time the sample was taken and the streamflow rating from this gage. The second grab sample was collected by dipping the churn at the centroid of flow from the left bank. At the time of collection, the stream was unsafe to wade and appeared to be well mixed. The average discharge was 103 $\mathrm{ft}^{3} / \mathrm{s}$ (fig. 8). Discharge associated with this grab sample was determined using the stage at the mean time of the grabsample collection and the streamflow rating from this gage. A laboratory duplicate sample was collected at this site.

The automatic sampler collected a total of 24 samples during a 3-hour period. As mentioned above, one of the first three samples was used for the first grab sample. With the remaining samples, a flow-weighted time-composite sample was created. The composite sample consisted of 20 samples collected during a 2.5-hour period. The average discharge was $366 \mathrm{ft}^{3} / \mathrm{s}$ (fig. 8). The peak discharge was $804 \mathrm{ft}^{3} / \mathrm{s}$ (14:31) on November 29, 2003. 


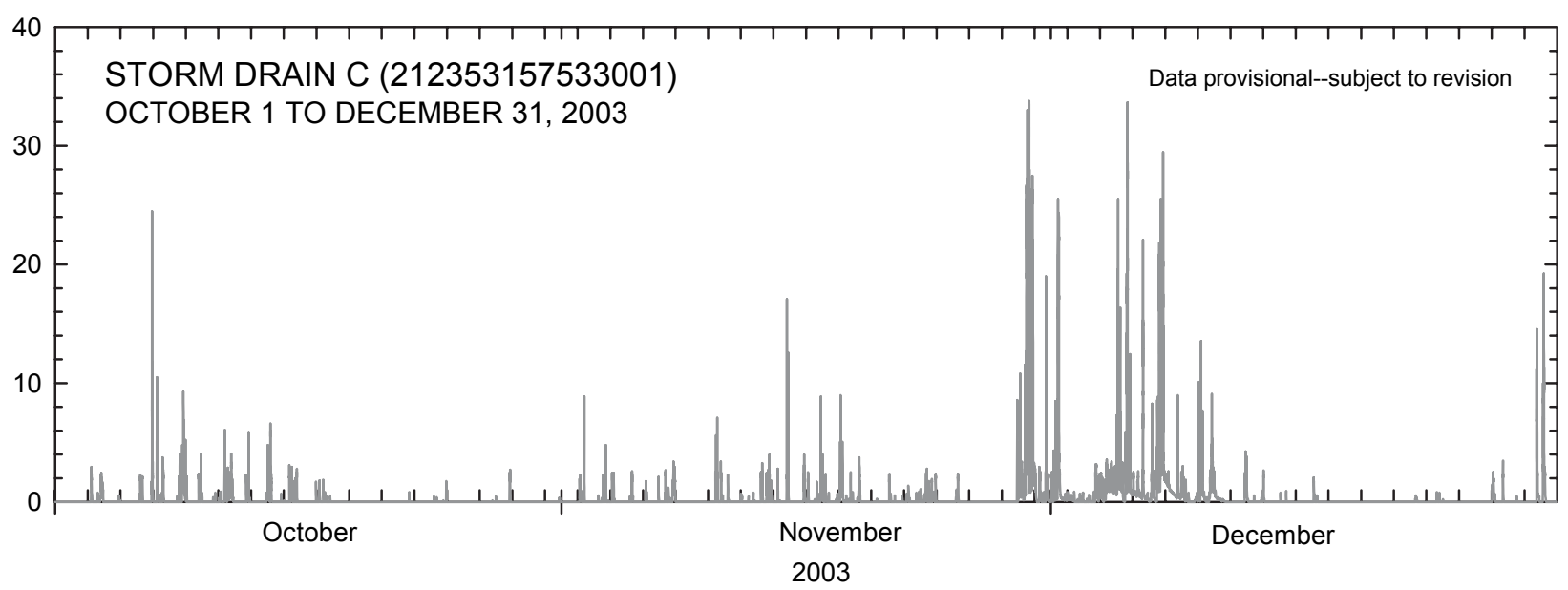

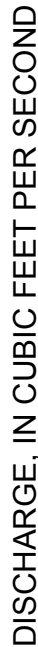
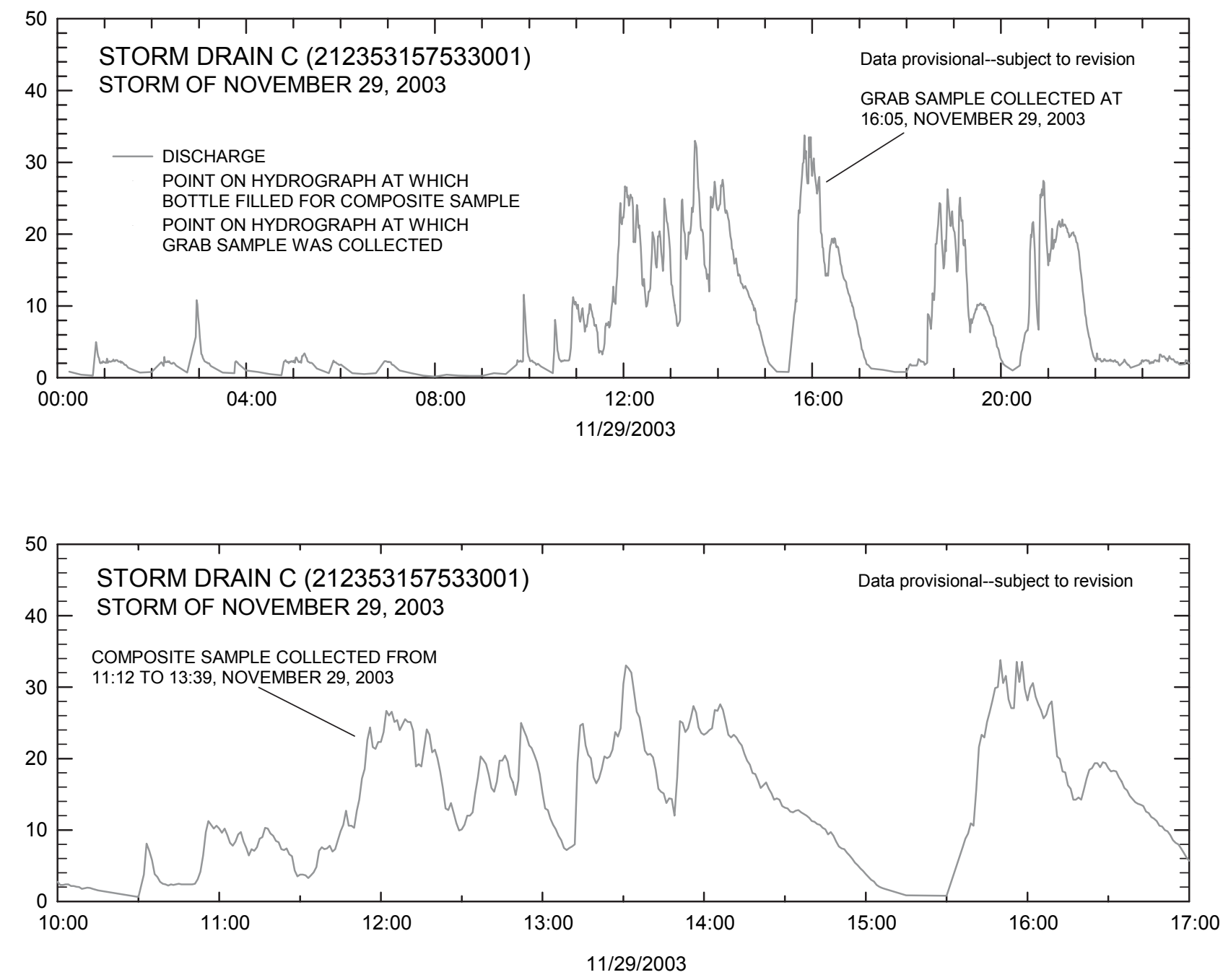

Figure 6. Stream discharge at Storm drain C station (212353157533001) for October 1 to December 31, 2003; detail of the 24-hour period of November 29, 2003; and detail of the 7-hour period from 10:00 to 17:00 November 29, 2003, Oahu, Hawaii. 


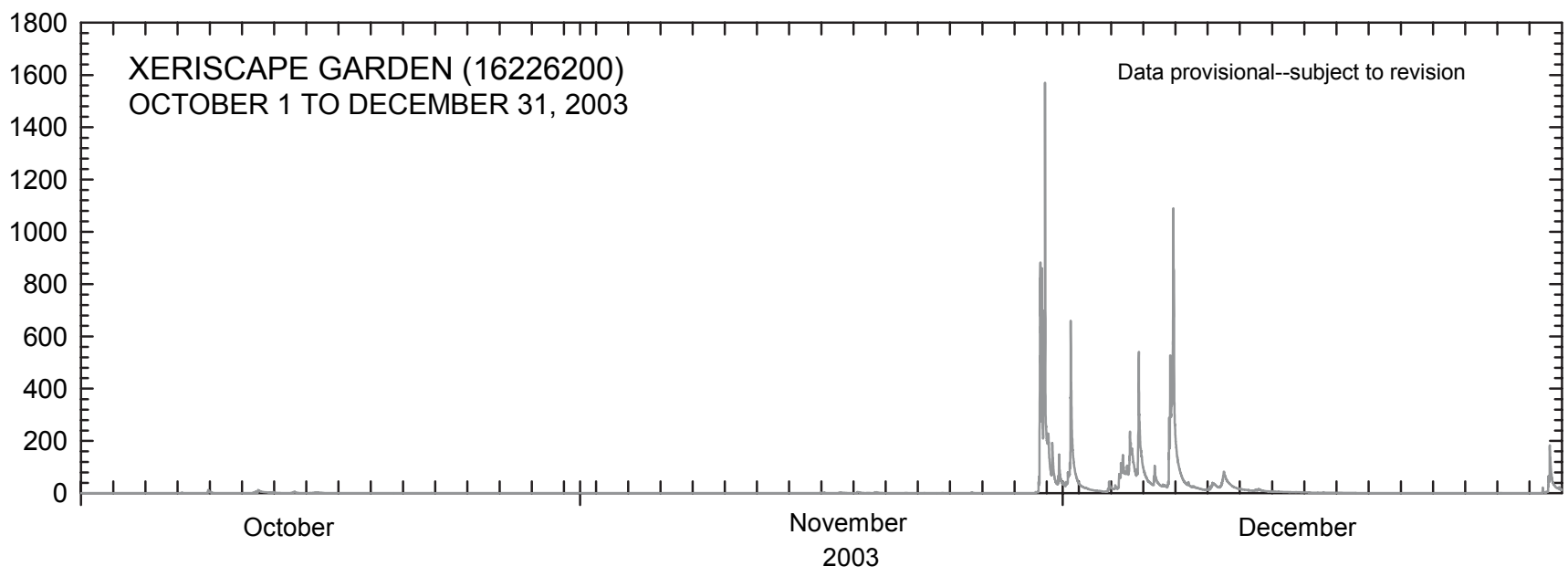

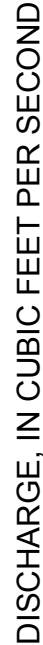
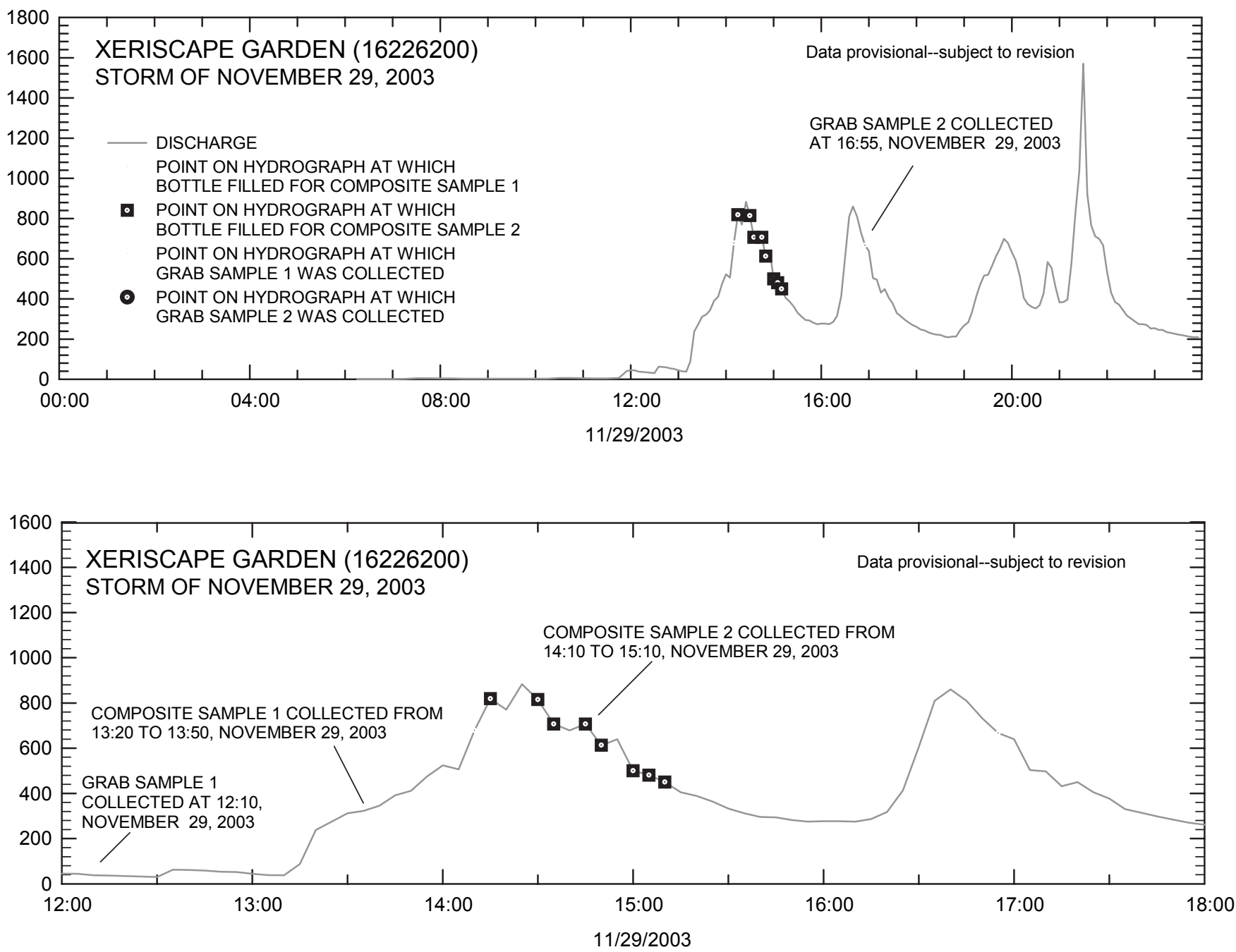

Figure 7. Stream discharge at Xeriscape garden station (16226200) for October 1 to December 31, 2003; detail of the 24-hour period of November 29, 2003; and detail of the 6-hour period from 12:00 to 18:00 November 29, 2003, Oahu, Hawaii. 

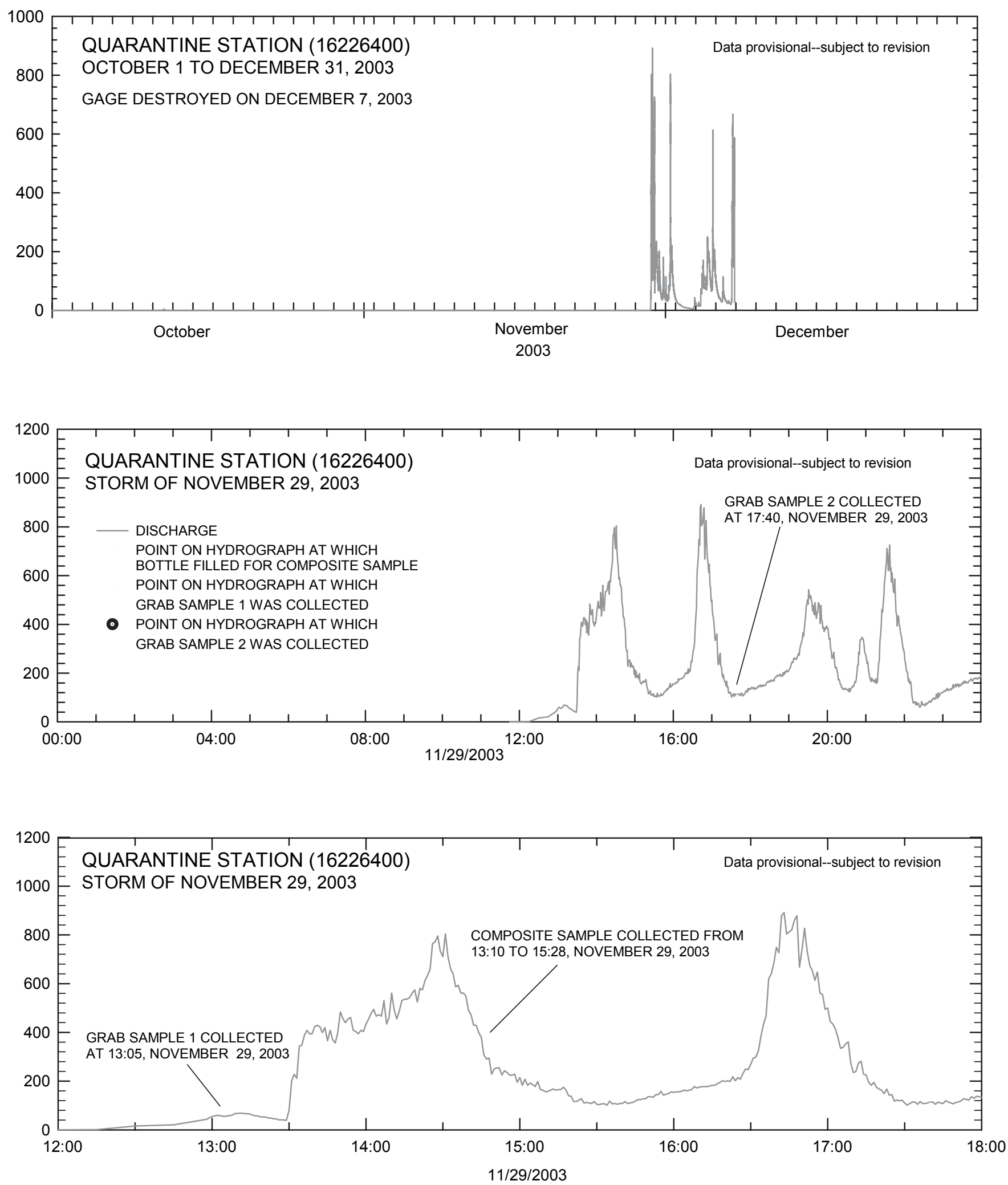

Figure 8. Stream discharge at Quarantine station (16226400) for October 1 to December 31, 2003; detail of the 24-hour period of November 29, 2003; and detail of the 6-hour period from 12:00 to 18:00 November 29, 2003, Oahu, Hawaii. 


\section{First Quarter 2004 - January 1 to March 31, 2004}

During this quarter, two storms were sampled. A partial storm sample was collected from Storm drain C and Xeriscape garden during the storm of January 22-25, 2004. All five sites were sampled during the storm of February 26-27, 2004.

\section{Storm of January 22-25, 2004}

The first storm of the quarter was during January 22-25, 2004. Only Storm drain C and Xeriscape garden sites had sufficient flow to sample. Hydrographs of streamflow at Storm drain $\mathrm{C}$ and Xeriscape garden during the storm of January 22-25, 2004 are shown in figures 9 and 10, respectively. The grab-sample collection time and composite-sample collection beginning and ending times are displayed on the hydrographs (figs. 9-10). The measured discharges for the grab-samples and average discharges during the collection of the flowweighted time-composite samples are shown in appendix B. Two composite samples were collected at Storm drain C. One grab and three composite samples were collected at Xeriscape garden. Discharges at Bridge 8, Quarantine station and Stadium were too low for grab sample collection. FC and BOD samples were not collected.

Storm drain C.--Two composite samples were collected and analyzed for TDS, TSS, and metals only. The nutrient holding times were exceeded. Both composite samples were not flow-weighted. The first composite was collected on January 22,2004 . Four automatic samples, representing the first flush, were used to create the composite. The discharge was $9.2 \mathrm{ft}^{3} / \mathrm{s}$ (fig. 9). The peak discharge was $22 \mathrm{ft}^{3} / \mathrm{s}$ (23:21) on January 22,2004 . The second composite sample was collected on January 25,2004 . Three automatic samples were used to create the composite. The average discharge was $18 \mathrm{ft}^{3} / \mathrm{s}$ (fig. 9). The peak discharge was $33 \mathrm{ft}^{3} / \mathrm{s}$ (17:00) on January 25 , 2004.

Xeriscape garden.--The grab sample was collected at the centroid of flow with an isokinetic sampler. Discharge was measured concurrently with the sample collection using a current meter and was $9.51 \mathrm{ft}^{3} / \mathrm{s}$. Three composite samples were collected and none were flow-weighted. The first composite was collected on January 22, 2004. Six automatic samples, representing the first flush, were used to create the composite. The average discharge was $52 \mathrm{ft}^{3} / \mathrm{s}$ (fig. 10). The peak discharge was $61 \mathrm{ft}^{3} / \mathrm{s}(06: 10)$ on January 22, 2004. The second composite sample was collected on January 23, 2004 and only TDS, TSS, and metals were analyzed. Nutrient holding times were exceeded. Four automatic samples were used to create the composite. The average discharge was $80 \mathrm{ft}^{3} / \mathrm{s}$ (fig. 10). The peak discharge was $112 \mathrm{ft}^{3} / \mathrm{s}(01: 40)$ on January 23, 2004. The third composite was collected on January 25, 2004 and only TDS, TSS, and metals were analyzed. Nutrient holding times were exceeded. Four automatic samples were used to create the composite. The average discharge was $79 \mathrm{ft}^{3} / \mathrm{s}$ (fig. 10). The peak discharge was $114 \mathrm{ft}^{3} / \mathrm{s}$ (18:50) on January 25 , 2004.

\section{Storm of February 26-27, 2004}

Hydrographs of streamflow at Storm drain C and Xeriscape garden during the storm of February 26-27, 2004 are shown in figures 11 and 12, respectively. The grab-sample collection time and composite-sample collection beginning and ending times are displayed on the hydrographs (figs. 11-12). The measured discharges for the grab samples and average discharges during the collection of the flow-weighted time-composite samples are shown in appendix B. A total of three composite samples were collected, two from Storm drain $\mathrm{C}$ and one from Xeriscape garden. The grab, FC, and BOD samples were collected from all five sites.

Bridge 8.--A grab sample was collected by dipping the churn at the centroid of flow from the left bank. At the time of sample collection, the stream was unsafe to wade and appeared to be well mixed. A field duplicate was collected at this site. Discharge associated with the grab sample was determined using the stage at the mean time of the grab-sample collection and the streamflow rating for this site and was $721 \mathrm{ft}^{3} / \mathrm{s}$.

Storm drain C.--A grab sample was collected at the centroid of flow in the storm drain by directly submersing the churn. At the time of the manual-grab sample, the discharge was $1.8 \mathrm{ft}^{3} / \mathrm{s}$ (fig. 11). Discharge associated with the grab sample was determined using the stage at the mean time of the grab-sample collection and the streamflow rating for this gage.

The automatic sampler collected a total of 17 samples during a 2.5-hour period. Two flow-weighted time-composite samples were created. Two automatic samples were omitted due to the large time difference between each of the samples and one sample bag was not filled. The time differences ranged from 15-45 minutes. The first composite consisted of the first 7 samples collected during a 30 -minute period. The peak discharge was $19 \mathrm{ft}^{3} / \mathrm{s}$ on February 26, 2004 (14:13). The average discharge was $14 \mathrm{ft}^{3} / \mathrm{s}$. The second composite consisted of the last 7 samples collected during a 50-minute period. The peak discharge was $32 \mathrm{ft}^{3} / \mathrm{s}$ on February 26, 2004 (15:44). The average discharge was $17 \mathrm{ft}^{3} / \mathrm{s}$.

Xeriscape garden.--The grab sample was collected at the centroid of flow by dipping the churn from the right bank. At the time of collection, the stream was unsafe to wade and appeared to be well mixed. Discharge associated with the grab sample was determined using the stage at the mean time of the grab-sample collection and the streamflow rating for this gage. Discharge was $322 \mathrm{ft}^{3} / \mathrm{s}$.

Twenty-four samples from the automatic sampler were used to create a flow-weighted, time-composite sample. The automatic samples were collected over a 2-hour period. The peak discharge was $860 \mathrm{ft}^{3} / \mathrm{s}$ on February 27, 2004 at 15:40. The average discharge for the composite sample was $170 \mathrm{ft}^{3} / \mathrm{s}$.

Quarantine station.-- The grab sample was collected using the EWI method at 17 sampling points distributed every $1 \mathrm{ft}$ along the cross section of the stream. Stream width was about $18.0 \mathrm{ft}$. Discharge, measured concurrently with sample collection using a current meter, was $10.9 \mathrm{ft}^{3} / \mathrm{s}$. 


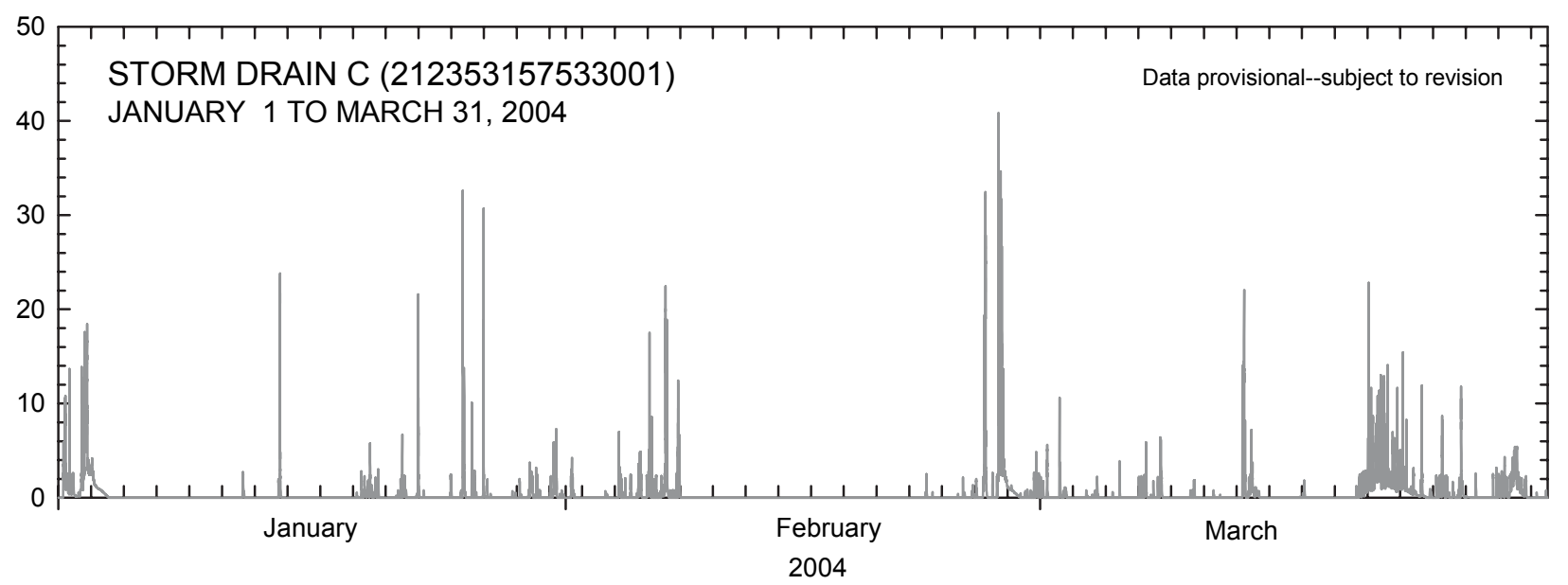

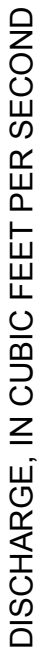
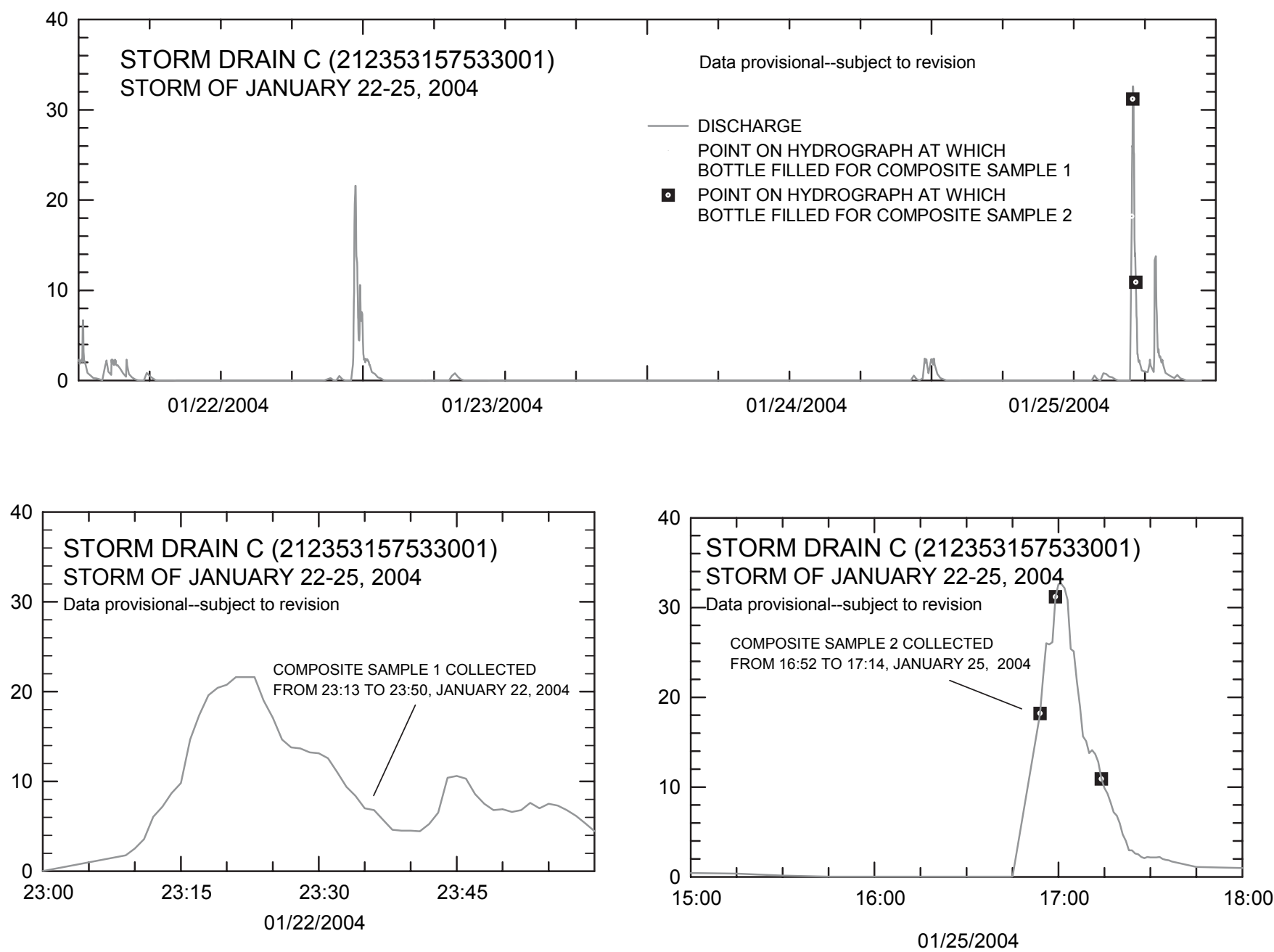

Figure 9. Stream discharge at Storm drain C station (212353157533001) for January 1 to March 31, 2004; detail of the 4-day period of January 22-25, 2004; detail of the 1-hour period from 23:00 to 24:00 January 22, 2004; and the detail of the 3-hour period from 15:00 to 18:00 January 25, 2004, Oahu, Hawaii. 


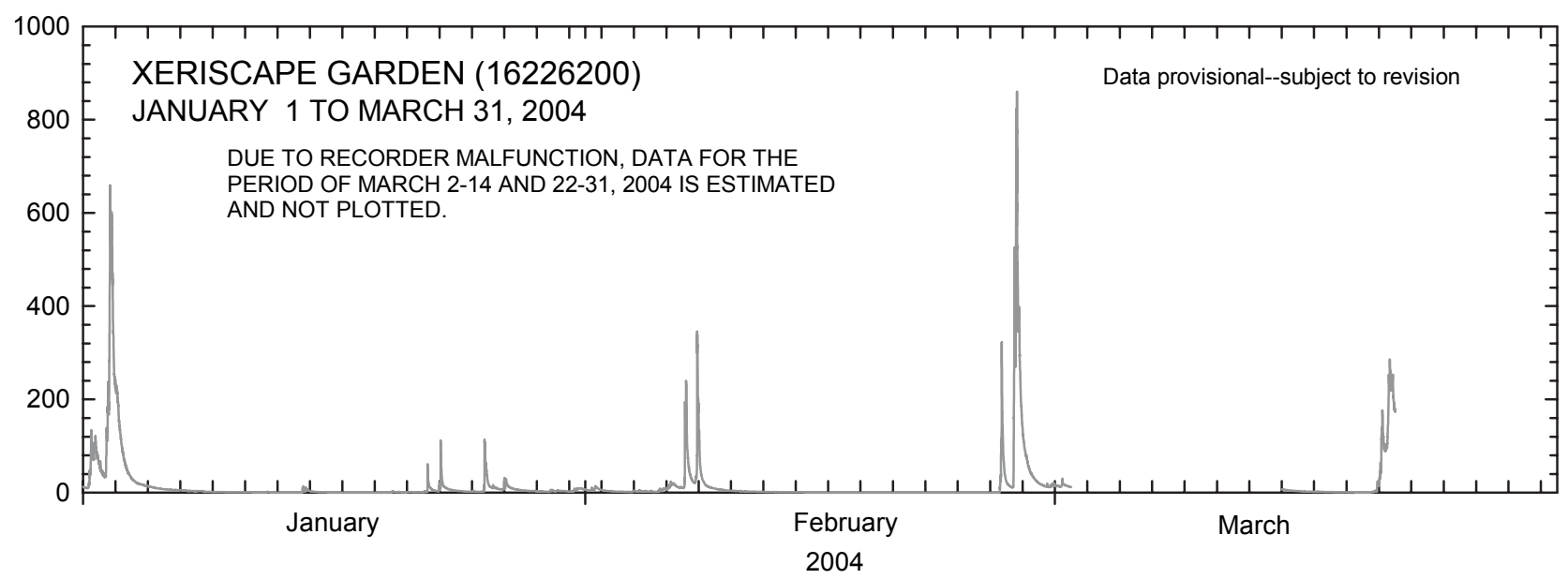

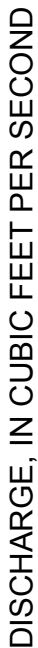
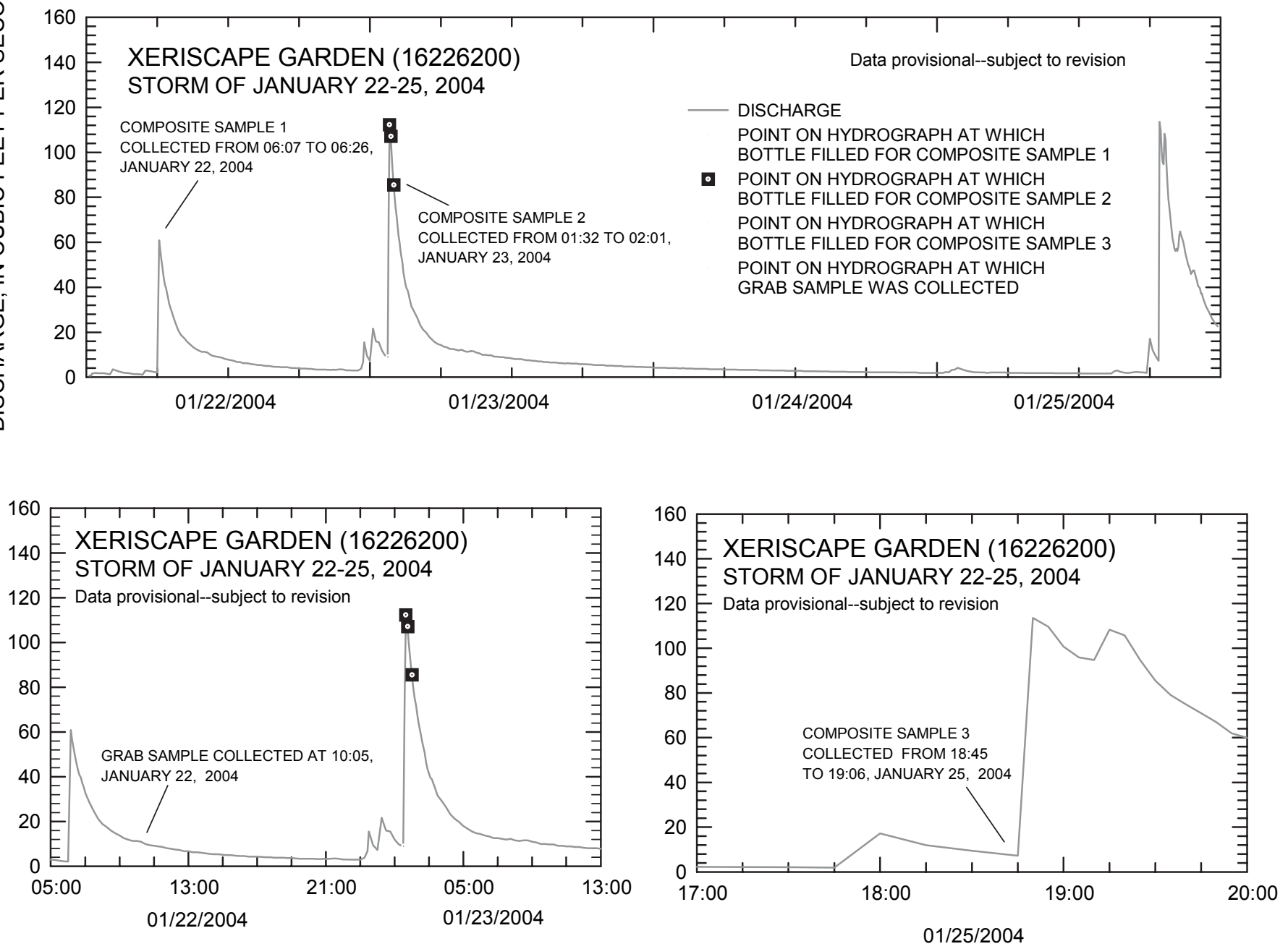

Figure 10. Stream discharge at Xeriscape garden station (16226200) for January 1 to March 31, 2004; detail of the 4-day period of January 22-25, 2004; detail of the 32-hour period from 05:00 January 22, 2004 to 13:00 January 23, 2004; and the detail of the 3-hour period from 17:00 to 20:00 January 25, 2004, Oahu, Hawaii. 


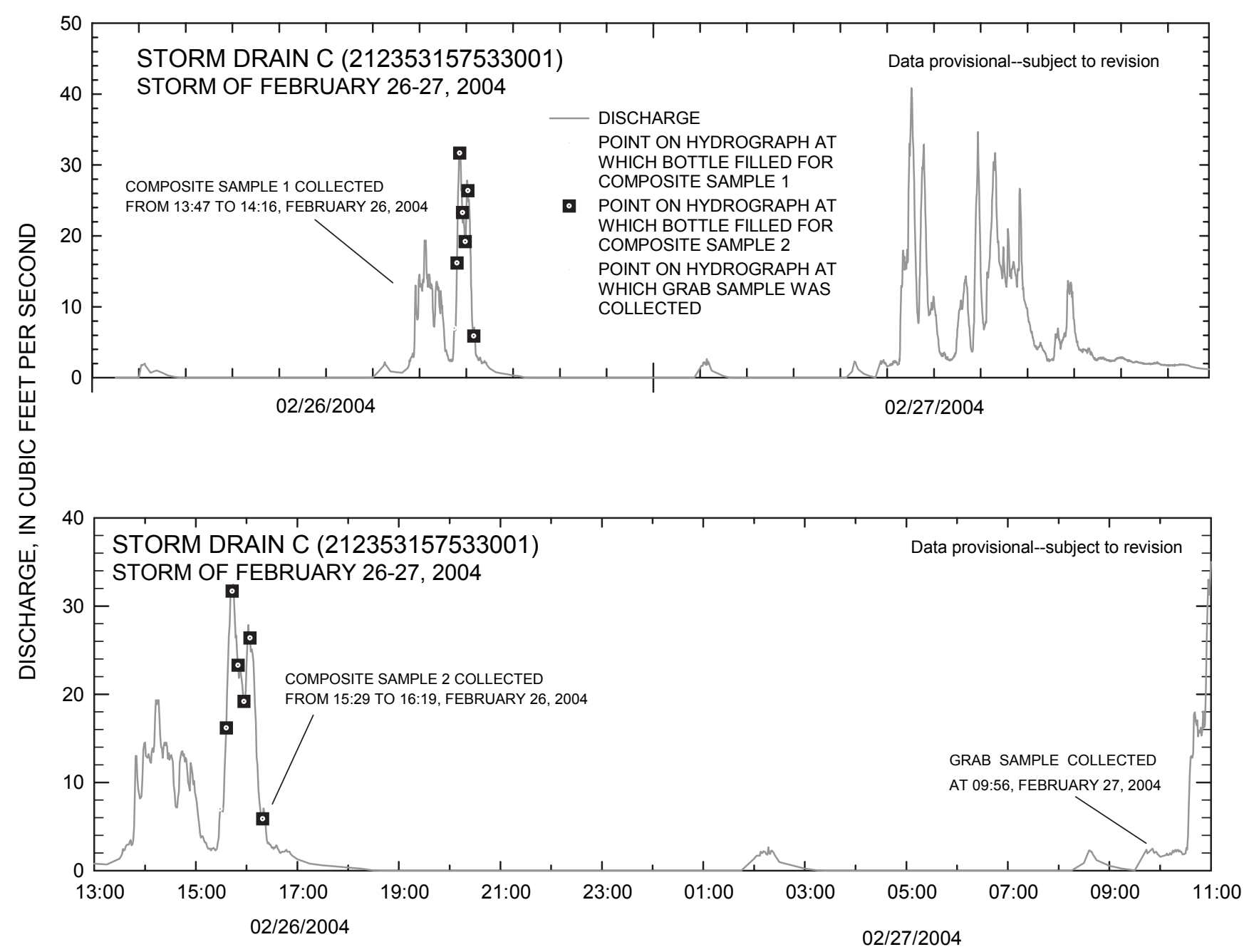

Figure 11. Stream discharge at Storm drain C station (212353157533001) for the 2-day period of February 26-27, 2004; and the detail of the 22-hour period from 13:00 February 26, 2004 to 11:00 February 27, 2004, 0ahu, Hawaii. 


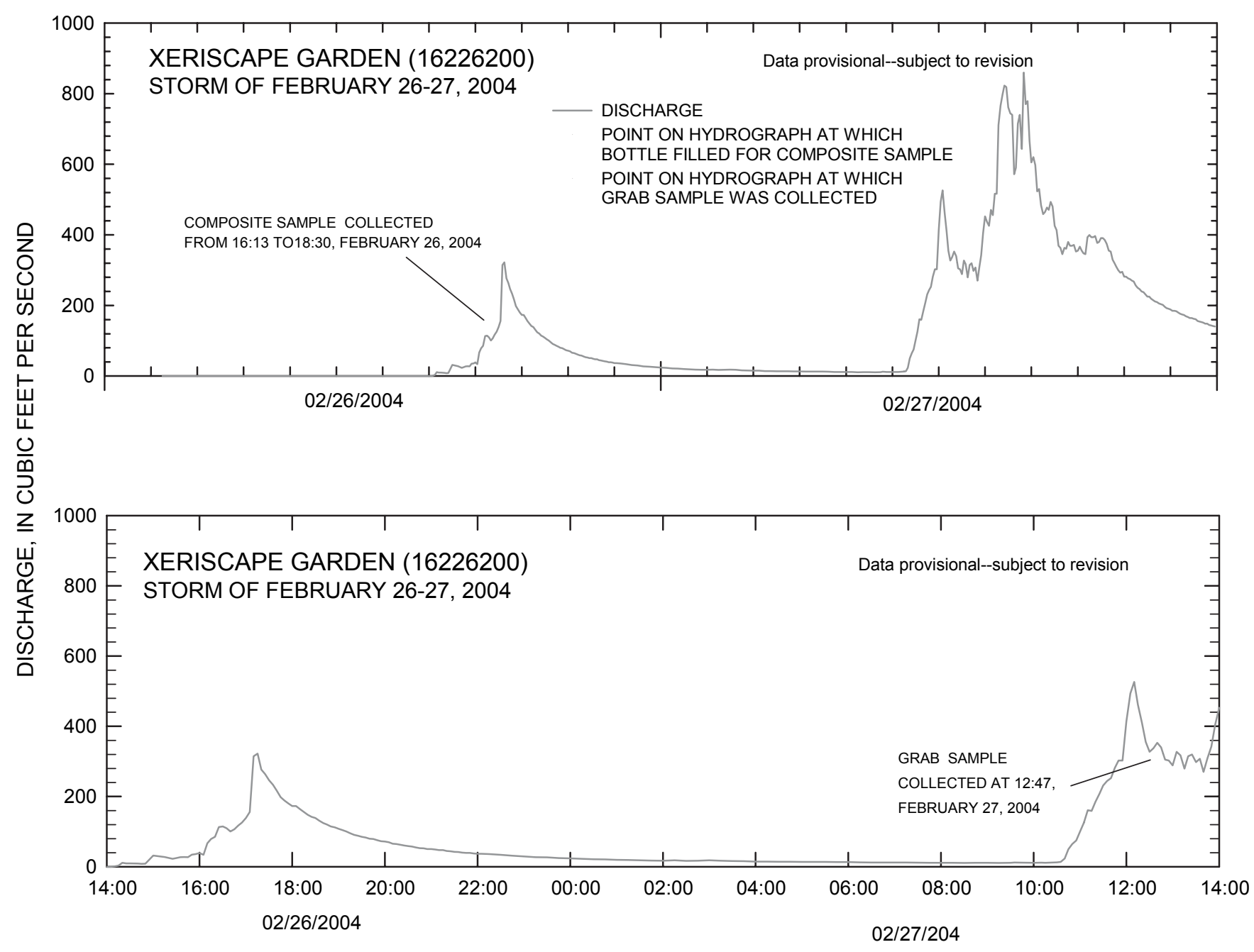

Figure 12. Stream discharge at Xeriscape garden station (16226200) for the 2-day period of February 26-27, 2004; and the detail of the 24-hour period from 14:00 February 26, 2004 to 14:00 February 27, 2004, Oahu, Hawaii. 
Stadium.--A grab sample was collected by dipping the churn off the side of the bridge at the centroid of flow. The stream was unsafe to wade during the time of sampling. The radar gun was used to measure surface velocity at 13 points distributed every $5 \mathrm{ft}$ along the cross section. The width of the cross section was about $75 \mathrm{ft}$. The area of the cross section was estimated by the depth of water and surveyed dimensions of the channel. Estimated discharge was 1,820 $\mathrm{ft}^{3} / \mathrm{s}$.

\section{Second Quarter 2004 - April 1 to June 30, 2004}

Hydrographs of streamflow at Storm drain C and Xeriscape garden for the period of April 1, 2003 to June 30, 2004 are shown in figure 13. During this period, automatic sampler thresholds at Storm drain C and Xeriscape garden sites were exceeded on May 15, 2004. However, rainfall did not generate enough flow at Storm drain $\mathrm{C}$ and Xeriscape garden to collect a sufficent number of samples for analysis during this quarter.

\section{QUALITY ASSURANCE}

Field and laboratory quality-assurance procedures were implemented as described in the DOT Storm Water Monitoring Program Plan (State of Hawaii Department of Transportation Highways Division, 2002). Eleven quality-assurance samples were collected: 7 samples were collected concurrently with storm samples during four of the storms, and 4 samples were collected between storms during routine cleaning of the sampling equipment. During storm sampling, field-duplicate samples, laboratory-duplicate samples, and laboratory-spike samples were collected at designated sampling sites for each storm. Results are not published in this report, but are available upon request.

All grab-sample collection equipment was cleaned before each storm and sampling. The automatic-sampler intake line from Storm drain $\mathrm{C}$ was cleaned 6 times during the year. However, due to the pattern of discharge in Storm drain $\mathrm{C}$, the

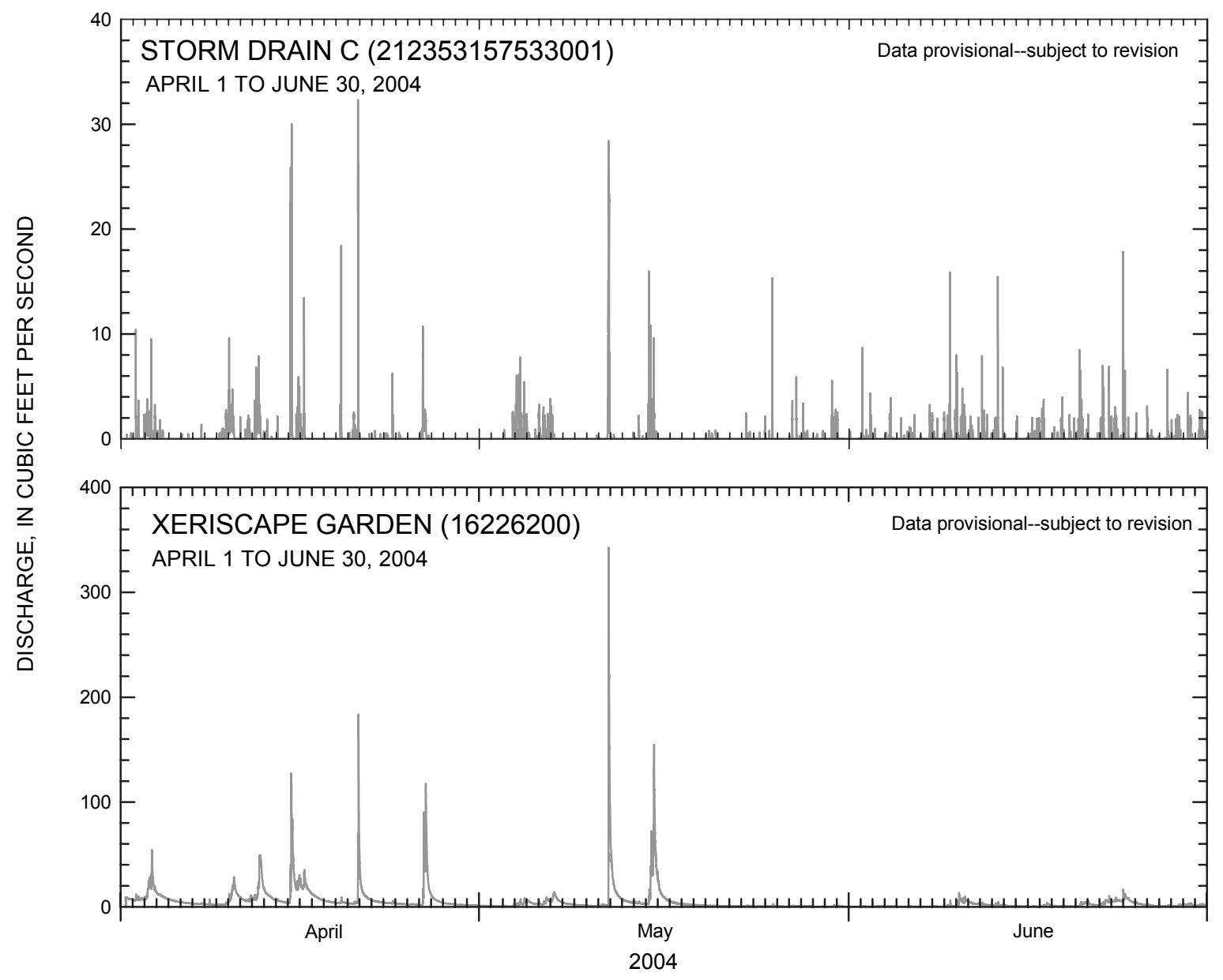

Figure 13. Stream discharge at Storm drain C (212353157533001) and Xeriscape garden (16226200) stations for April 1 to June 30, 2004, Oahu, Hawaii. 
sampler was triggered occasionally and samples were collected during brief rain showers. The intake line was potentially contaminated in this manner prior to the January 22-25, 2004 storm at Storm drain C.

In regards to the potential of contamination with the intake lines, it is important to note that the automatic sampler conducts a rinse cycle prior to every sample collected. The rinse cycle routine is as follows: 1) sample line is first purged by air, 2) water is pumped up the line to a sensor located before the pump, 3) water is purged out, and 4) the sample is then collected. The rinse cycle minimizes possible contamination from water pumped during earlier storms and from previously pumped samples during the same storm, and conditions the intake lines with sample water prior to collection.

IBW field-blank samples from the automatic samplers were collected during every quarter at: Storm drain C on July 24, 2003 and February 5, 2004 and at Xeriscape garden on December 18, 2003 and May 26, 2004. Intake lines were cleaned prior to the collection of IBW field-blank samples. These field samples were analyzed for nutrients, cadmium, copper, lead, and zinc. All constituents were detected in trace amounts, except for zinc. Zinc was detected in all the blank samples. Concentrations of zinc ranged from 2 to $27 \mu \mathrm{g} / \mathrm{L}$. IBW field-blank samples collected at Storm drain C on July 24, 2003 had the highest concentration of zinc detected. Zinc has been detected in previous years of this sampling project. The minimum reporting level of zinc is $2 \mu \mathrm{g} / \mathrm{L}$.

\section{REFERENCES CITED}

Childress, C.J.O., Foreman, W.T., Connor, B.F., and Maloney, T.J., 1999, New reporting procedures based on longterm method detection levels and some considerations for interpretations of water-quality data provided by the U.S. Geological Survey National Water Quality Laboratory: U.S. Geological Survey Open-File Report 99-193, 19p.

Fishman, M.J., and Friedman, L.C., eds., 1989, Methods for determination of inorganic substances in water and fluvial sediments ( 3 d ed.): U.S. Geological Survey Techniques of Water-Resources Investigations, book 5, chap. A1, 545 p.

Fishman, M.J., ed., 1993, Methods of analysis by the U.S. Geological Survey National Water Quality Laboratory-Determination of inorganic and organic constituents in water and fluvial sediments: U.S. Geological Survey OpenFile Report 93-125, 217 p.

Friedman, L.C., and Erdmann, D.E., 1982, Quality assurance practices for the chemical and biological analyses of water and fluvial sediments: U.S. Geological Survey Techniques of Water-Resources Investigations, book 5, chap. A6, 181 p.
Patton, C.J., and Truitt, E.P., 1992, Methods of analysis by the U.S. Geological Survey National Water Quality Laboratory-Determination of total phosphorus by a Kjedahl digestion method and an automated colorimetric finish that include dialysis: U.S. Geological Survey Open-File Report 94-455, 42 p.

Pritt, J.W., and Raese, J.W., eds., 1992, Quality assurance/ quality control manual National Water Quality Laboratory: U.S. Geological Survey Open-File Report 94-708, 26 p.

Rantz, S.E., and others, 1982, Measurement and computation of streamflow: Volume 1. Measurement of stage and discharge, Volume 2. Computation of discharge: U.S. Geological Survey Water-Supply Paper 2175, 284 p. and 346 p.

Sauer, V.B., 2002, Standards for the analysis and processing of surface-water data and information using electronic methods: U.S. Geological Survey Water-Resources Investigations Report 01-4044, 92 p.

State of Hawaii Department of Transportation Highways Division, 2002, Annual storm water monitoring program plan 2002-2003, 20 p. + ap.

U.S. Environmental Protection Agency, Office of Water, 1993, NPDES Storm water sampling guidance manual, prepared by C.K. Smoley, CRC Press, Inc. 165 p.

U.S. Geological Survey, 2004a, Real-time data, http://hi.water. usgs.gov/, accessed on July 7, 2004.

U.S. Geological Survey, 2004b, Water-quality data for Hawaii, http://waterdata.usgs.gov/hi/nwis/qwdata, accessed on July 7, 2004.

Wilde, F.D., Radtke, D.B., Gibs, Jacob, and Iwatsubo, R.T., 1998, National field manual for the collection of waterquality data, U.S. Geological Survey Techniques of Water-Resources Investigations, book 9, chap. A4, $114 \mathrm{p}$. 


\section{APPENDIX A: Discharge-Reporting and Load-Calculation Methods}

This appendix further defines the methods used for reporting discharge data and constituent concentration data, and the methods for calculating constituent loads. To adequately qualify the quality of discharge and water-quality data, values are rounded off to the number of significant figures that best describe the precision of the measurement.

Discharge data.--Table 2 shows the number of significant figures and rounding limits for the range of discharges in this study. Discharges measured by current meter or float measurement techniques follow guidelines for measured discharges. Discharges determined by streamflow rating or by averaging follow guidelines for daily mean discharges (Sauer, 2002). Measured discharges have more significant figures because they are considered more precise to more significant figures than averaged discharges.

Table 2. Significant figures and rounding limits for measured, streamflow-rating, and averaged discharges

$\left[\mathrm{ft}^{3} / \mathrm{s}\right.$, cubic feet per second; <, actual value is less than shown; , actual value is greater than or equal to value shown]

\begin{tabular}{cccccc}
\hline & \multicolumn{2}{c}{ Measured discharge } & & \multicolumn{2}{c}{$\begin{array}{c}\text { Streamflow-rating and averaged } \\
\text { discharges }\end{array}$} \\
\cline { 2 - 3 } \cline { 5 - 6 } $\begin{array}{c}\text { Range of discharge } \\
\left(\mathbf{f t}^{3} / \mathbf{s}\right)\end{array}$ & $\begin{array}{c}\text { Significant } \\
\text { figures }\end{array}$ & Rounding limit & & $\begin{array}{c}\text { Significant } \\
\text { figures }\end{array}$ & Rounding limit \\
\hline$<0.10$ & 2 & thousandths & & 1 & hundredths \\
0.10 to 0.99 & 2 & hundredths & & 2 & hundredths \\
1.0 to 9.9 & 3 & hundredths & & 2 & tenths \\
10 to 99 & 3 & tenths & & 2 & units \\
100 & 3 & variable & & 3 & variable \\
\hline
\end{tabular}

Calculation of loads.--Table 3 shows the conversion factors used for determining constituent loads. Constituent loads for all analyses are reported as pounds per day (lbs/day) except for fecal coliform, which is reported as billion colonies per day. All loads are the product of constituent concentration multiplied by associated discharge and the appropriate conversion factor (equation 1). Concentrations are reported in milligrams per liter (mg/L) or micrograms per liter ( $\mu \mathrm{g} / \mathrm{L})$, except for fecal coliform, which is reported in most probable number (of colonies) per 100 milliliters (MPN/100 ml). Four significant figures are used for the conversion factors; however, the load value is reported with the lesser number of significant figures of the values of concentration and discharge.

$$
\begin{aligned}
& Q(C) K=L \\
& \text { Where } \quad \mathrm{Q}=\text { discharge }\left(f t^{3} / S\right) \\
& \mathrm{C}=\text { constituent concentration }(m g / L, \mu g / L \text { or } M P N / 100 m l) \\
& \mathrm{K}=\text { conversion factor } \\
& \mathrm{L}=\text { constituent load }(l b s / d a y)
\end{aligned}
$$

Table 3. Conversion factors for computing daily loads from constituent concentration and discharge

[mg/L, milligrams per liter; $\mu \mathrm{g} / \mathrm{L}$, micrograms per liter; MPN/100 mL, most probable number (of colonies) per 100 milliliters; lbs/day, pounds per day]

\begin{tabular}{ccc}
\hline Unit of concentration & $\begin{array}{c}\text { Conversion } \\
\text { factor }^{\mathbf{a}}\end{array}$ & Load unit \\
\hline $\mathrm{mg} / \mathrm{L}$ & 5.394 & lbs/day \\
$\mu \mathrm{g} / \mathrm{L}$ & 0.005 & lbs/day \\
$\mathrm{MPN} / 100 \mathrm{~mL}$ & 0.024 & billion colonies per day \\
\hline
\end{tabular}

\footnotetext{
${ }^{a}$ All conversion factors are based on discharge in cubic feet per second.
} 